\title{
Thermochronometer record of central Andean Plateau growth, Bolivia $\left(19.5^{\circ} \mathrm{S}\right)$
}

\author{
J. B. Barnes, ${ }^{1}$ T. A. Ehlers, ${ }^{1}$ N. McQuarrie, ${ }^{2}$ P. B. O’Sullivan, ${ }^{3}$ and S. Tawackoli ${ }^{4}$ \\ Received 13 June 2007; revised 14 January 2008; accepted 29 February 2008; published 23 May 2008.
}

[1] Quantifying the timing, magnitude, and rates of exhumation and deformation across the central Andes is a prerequisite for understanding the history of plateau rise. We present 23 new apatite and zircon fission track thermochronometer samples to chronicle the exhumation and deformation across the entire $(\sim 500 \mathrm{~km})$ Andean fold-thrust belt at $\sim 19.5^{\circ} \mathrm{S}$ in Bolivia. Exhumation and deformation are constrained with inverse thermal modeling of the thermochronometer data, regional stratigraphy, geothermal gradients, and mass deficits inferred from a balanced section. Results suggest the following: (1) Initial exhumation of the Eastern Cordillera (EC) fore-thrust and back-thrust belts began in the late Eocene to early Oligocene (27$36 \mathrm{Ma}$ ) and continued in a distributed manner in the late Oligocene to early Miocene (19-25 Ma). Interandean zone (IA) exhumation began 19-22 Ma, followed by a third pulse of exhumation (11-16 Ma) in the EC backthrust belt and initial cooling in the westernmost Subandes (SA) 8-20 Ma. Finally, exhumation propagated eastward across the SA during the late Mio-Pliocene (2-8 Ma). (2) Exhumation magnitudes are spatially variable and range from maximums of $<8 \mathrm{~km}$ in the EC fore-thrust belt to average values of $\sim 4-7 \mathrm{~km}$ across the EC, $\sim 2.5-3 \mathrm{~km}$ in the Altiplano, $\sim 4-6 \mathrm{~km}$ in the IA, and $\sim 3 \mathrm{~km}$ in the SA. (3) Exhumation rates range from $\sim 0.1$ to $0.2 \mathrm{~mm} / \mathrm{a}$ in the $\mathrm{EC}$, from $\sim 0.1$ to $0.6 \mathrm{~mm} / \mathrm{a}$ in the IA, and from $\sim 0.1$ to $0.4 \mathrm{~mm} / \mathrm{a}$ to locally $1.4 \mathrm{~mm} / \mathrm{a}$ or more in the eastern SA. We synthesize similar constraints with sediments throughout Bolivia and characterize plateau development by (1) distributed deformation throughout the Altiplano and EC regions from $\sim 20$ to $40 \mathrm{Ma}$ with minor deformation continuing until $\sim 10 \mathrm{Ma}$, (2) contemporaneous cessation of most EC deformation and exhumation of the IA $\sim 20$ Ma implying establishment of the modern plateau width with significant, but unknown crustal thickness and elevation shortly

\footnotetext{
${ }^{1}$ Department of Geological Sciences, University of Michigan, Ann Arbor, Michigan, USA.

${ }^{2}$ Department of Geosciences, Princeton University, Princeton, New Jersey, USA.

${ }^{3}$ Apatite to Zircon, Inc., Viola, Idaho, USA

${ }^{4}$ Técnico Internacional Programa APEMIN-II, Oruro, Bolivia.

Copyright 2008 by the American Geophysical Union. 0278-7407/08/2007TC002174
}

thereafter by $\sim 15-20 \mathrm{Ma}$, and (3) dominantly eastward propagation of deformation from the IA since $\sim 20 \mathrm{Ma}$ with minor out-of-sequence deformation in the central to eastern SA. Citation: Barnes, J. B., T. A. Ehlers, N. McQuarrie, P. B. O'Sullivan, and S. Tawackoli (2008), Thermochronometer record of central Andean Plateau growth, Bolivia (19.5 $\left.{ }^{\circ} \mathrm{S}\right)$, Tectonics, 27, TC3003, doi:10.1029/2007TC002174.

\section{Introduction}

[2] Orogenic plateaus are important because of their influence on mantle dynamics, orographic precipitation, physical weathering rates, and their ability to trap large sediment volumes in their protected interiors [e.g., Isacks, 1988; Molnar et al., 1993; Masek et al., 1994; Ruddiman et al., 1997; Beaumont et al., 2001; Sobel et al., 2003]. Although models can simulate plateau growth by temperature-dependent viscosity variations in a shortening and thickening crust, they are limited by incomplete knowledge of the kinematic histories of plateau formation [Wdowinski and Bock, 1994; Royden, 1996; Willett and Pope, 2004]. Constraining the kinematics, timing, and rates of plateau erosion and deformation is necessary to understand both the processes involved in plateau formation as well as the conditions under which they develop [e.g., Oncken et al., 2006]. It is also important to quantify the along-strike variations in the kinematic and erosion history of the central Andean plateau to evaluate the mechanisms that determine plateau width. In this study, we present new data and interpretations that chronicle the exhumation and deformation across the eastern flank of the central Andean plateau at its widest extent.

[3] The central Andean plateau occupies the core of the Andes, rests $\sim 3 \mathrm{~km}$ in average elevation, encompasses over $500,000 \mathrm{~km}^{2}$, and straddles humid to semiarid latitudes from southern Peru to northern Argentina (Figure 1) [e.g., Isacks, 1988]. Numerous processes have been proposed to influence Andean plateau evolution such as; crustal shortening/thickening [e.g., Lamb and Hoke, 1997; Kley and Monaldi, 1998; Elger et al., 2005], plate kinematics [e.g., Pardo-Casas and Molnar, 1987; Oncken et al., 2006], topography and subduction geometry [Gephart, 1994; Iaffaldano et al., 2006], inherited structure and stratigraphy [Allmendinger and Gubbels, 1996; Kley et al., 1999], thermal weakening [Isacks, 1988; Wdowinski and Bock, 1994; Allmendinger et al., 1997; Lamb and Hoke, 1997], and variable erosion resulting from latitudinal precipitation gradients [Masek et al., 1994; Horton, 1999; Montgomery et al., 2001; Lamb and Davis, 2003; Sobel et al., 2003; Gillis et al., 2006]. 


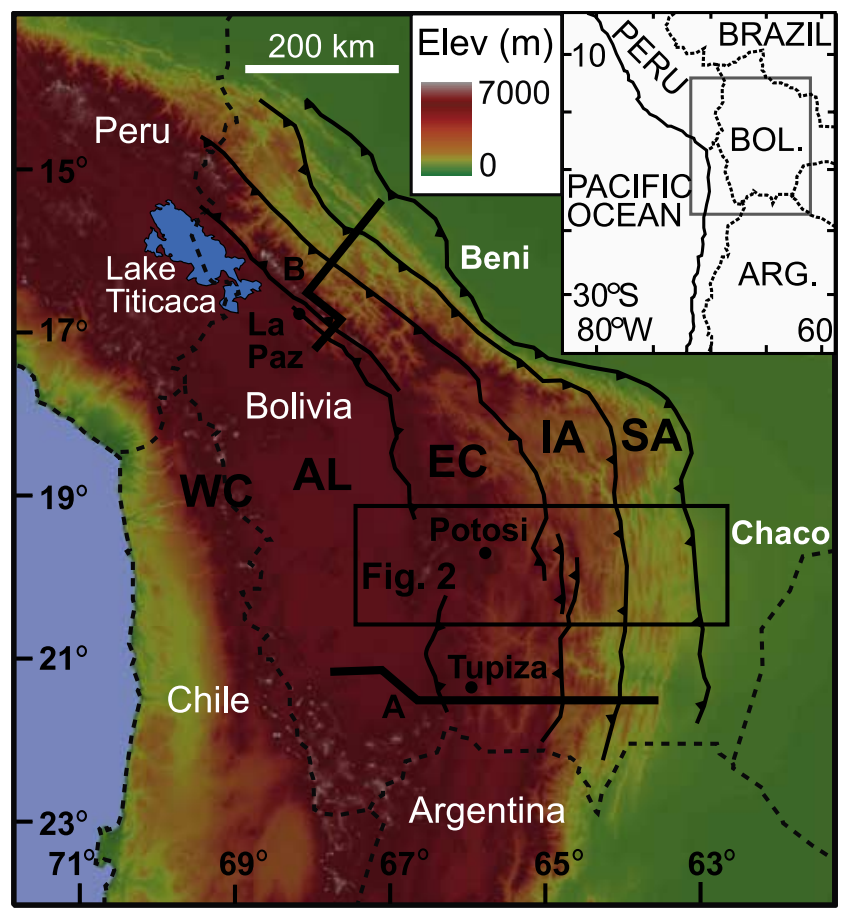

Figure 1. The central Andean fold-thrust belt and plateau in Bolivia. Topography is from the SRTM $90 \mathrm{~m}$ data set. Elev, elevation. Zone-bounding faults are modified from McQuarrie [2002]. Major zones: WC, Western Cordillera; AL, Altiplano; EC, Eastern Cordillera; IA, Interandean zone; SA, Subandes. Inset shows location in western central South America, and box outlines the study area in Figure 2. Solid lines are locations of two major additional thermochronometer data transects in the south (A, Scheuber et al. [2006] and Ege et al. [2007]) and north (B, e.g., Barnes et al. [2006]) discussed in the text.

[4] Observations of the lithospheric structure, sedimentary record, and various proxies have been used to deduce the chronology and mode of Andean plateau uplift. Deformation was initially assumed to begin in the late Oligocene ( $\sim 27 \mathrm{Ma})$ [Isacks, 1988; Sempere et al., 1990] and characterized by distributed shortening (pure shear) until $\sim 10 \mathrm{Ma}$ when it shifted to simple shear focused in the easternmost thin-skinned thrust belt of the Subandes where it continues today [Gubbels et al., 1993; Allmendinger and Gubbels, 1996]. However, earlier Eocene-Oligocene ( 30-40 Ma) deformation has now been well documented with mapping and seismic profiles [e.g., Elger et al., 2005], Cenozoic basin sediments [e.g., DeCelles and Horton, 2003; Horton, 2005] and thermochronometer-derived exhumation [e.g., Benjamin et al., 1987; Gillis et al., 2006; Ege et al., 2007]. These studies have argued that the Eocene to recent deformation has accumulated both broadly within the plateau region and propagated eastward toward the foreland. Perhaps most interestingly, mounting evidence inferred from erosion surface remnants [Kennan et al., 1997; Barke and Lamb, 2006], valley incision [Schildgen et al., 2007], and soil carbonate isotopes [Garzione et al., 2006; Ghosh et al., 2006] has lead to the postulation that $2-3+\mathrm{km}$ of rapid plateau surface uplift occurred $\sim 6-10$ Ma by lithospheric mantle delamination or lower crustal flow.

[5] In the Bolivian Andes $\left(\sim 15-20^{\circ} \mathrm{S}\right)$, plateau development is coupled to the central Andean fold-thrust belt where the kinematic history has been documented by sequential kinematic restorations of balanced cross sections [McQuarrie, 2002]. This kinematic linkage provides an opportunity to correlate the kinematics and timing of plateau deformation with its eastern flanking thrust belt. Unfortunately, imprecise age and exhumation constraints still exist on many of the structures in the thrust belt making it difficult (1) to detail a deformation chronology in order to test the sequential reconstructions, (2) to estimate the variations in the associated erosional response to the deformation, and (3) to use these constraints to improve our understanding of plateau growth. To address these shortcomings, we present a transect of new thermochronometer data at $\sim 19.5^{\circ} \mathrm{S}$ in southern Bolivia where both a kinematic reconstruction and a preliminary chronology of the deformation has already been proposed [McQuarrie et al., 2005]. This paper is a companion to McQuarrie et al. [2008] which integrates similar data sets across the central Andean foldthrust belt $\sim 500 \mathrm{~km}$ to the north at $15-17^{\circ} \mathrm{S}$.

[6] At $\sim 19.5^{\circ} \mathrm{S}$, the central Andean fold-thrust belt and plateau are broad, the climate is semiarid, and the topographic relief is subdued relative to northern Bolivia (Figure 1) [Isacks, 1988; Masek et al., 1994; Horton, 1999]. In this paper, we (1) present apatite and zircon fission track (AFT and ZFT) thermochronology results from 23 samples to quantify the long-term deformation and exhumation history across the entire thrust belt at $\sim 19.5^{\circ} \mathrm{S}$ (Figures 1 and 2), (2) quantify sample cooling histories with inverse thermal modeling of the AFT data, (3) incorporate the results within the regional stratigraphy and structure, (4) refine the timing of deformation inferred from the cooling histories, and (5) estimate the spatial variability of exhumation magnitudes with multiple methods. Finally, we compare our results to those in southern Bolivianorthernmost Argentina $\left(19-23^{\circ} \mathrm{S}\right)$ and then throughout Bolivia $\left(15-21.5^{\circ} \mathrm{S}\right)$. The combination of new and previous thermochronometer, sedimentary, and geomorphic records allows an analysis of spatial and temporal variations in deformation in southern Bolivia, and finally a more complete and generalized history of central Andean plateau growth throughout Bolivia.

\section{Geologic Setting}

\subsection{Central Andean Fold-Thrust Belt and Plateau}

[7] The Andes reach their greatest west-east width of $500 \mathrm{~km}$ in southern Bolivia (Figure 1). The central Andean fold-thrust belt is commonly divided into the Western Cordillera, the Altiplano, the Eastern Cordillera (EC), the Interandean zone (IA), and the Subandes (SA). The Western Cordillera is the modern volcanic arc that marks the PacificAltiplano drainage divide. The Altiplano is a low-relief, internally drained basin filled with Tertiary sediments and volcanics. The EC is the highest relief region consisting of deformed, predominantly Paleozoic sedimentary rocks with 


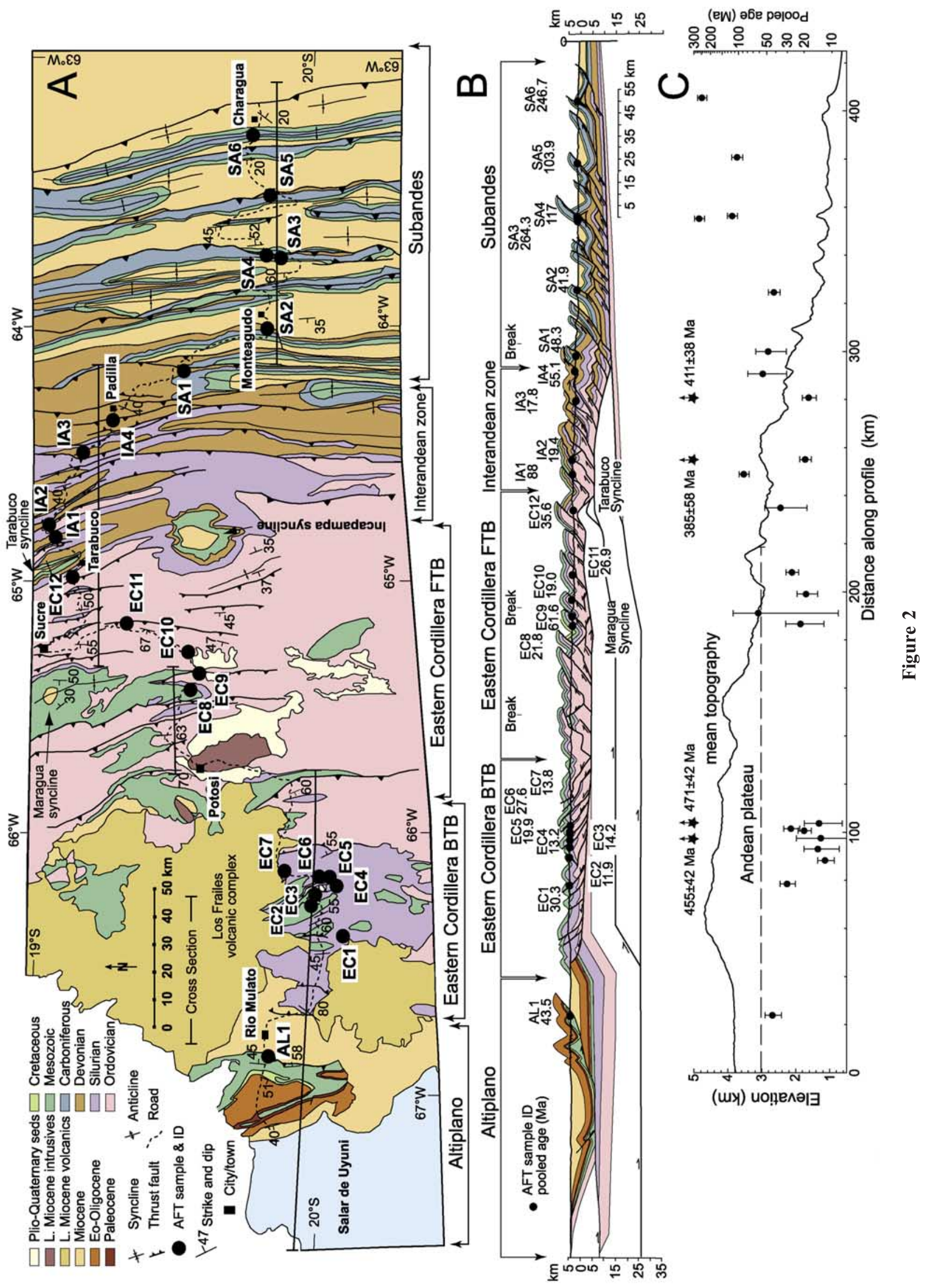


overlying Tertiary volcanism that mark the eastern drainage divide of the Altiplano. The IA and SA zones step progressively downward in topographic elevation and upward in structural depth eastward exposing mostly Devonian and Carboniferous through Mesozoic and Tertiary rocks, respectively (Figure 2) [McQuarrie, 2002]. Large basement structures are thought to be a principal cause for these various structural levels of exposure that differentiate the Altiplano through SA (Figure 2b) [Kley, 1996, 1999; McQuarrie, 2002; Müller et al., 2002]. The Andean plateau is the high-elevation landmass commonly defined by $>3 \mathrm{~km}$ average elevation that includes the entire Altiplano and a significant portion of the EC (Figure 2c) [after Isacks, 1988].

[8] The central Andean fold-thrust belt encompasses the eastern Altiplano to SA and is an east vergent, thick to thinskinned retroarc fold belt that is the result of strain accumulation from the South American plate overriding the Nazca plate (Figure 1) [e.g., Isacks, 1988; Allmendinger et al., 1997; Jordan et al., 1997]. The EC is somewhat unique because it has accommodated the strain with both a west vergent back-thrust belt and an east vergent fore-thrust belt [e.g., Roeder, 1988; McQuarrie and DeCelles, 2001]. In the central Andes $\left(\sim 14-24^{\circ} \mathrm{S}\right)$, structural and stratigraphic data have constrained the deformation in the $\mathrm{EC}$ from late Eocene-Oligocene $(\sim 25-40 \mathrm{Ma})$ to early late Miocene $(\sim 8-20 \mathrm{Ma})$ at which point it migrated eastward into the SA [e.g., Sempere et al., 1990; Kley, 1996; Kennan et al., 1997; Kley et al., 1997; Lamb and Hoke, 1997; Elger et al., 2005; Horton, 2005]. To date, two major transects of thermochronometer data exist across the thrust belt in Bolivia; in the far north near Peru at $15-17^{\circ} \mathrm{S}$ and in the far south near Argentina at $\sim 21.5^{\circ} \mathrm{S}$ (Figure 1; lines A and B). In the north, initial late Eocene-Oligocene ( $25-40 \mathrm{Ma})$ rapid exhumation began in the EC followed by widespread middle to late Miocene to present $(\sim 0-15 \mathrm{Ma})$ exhumation across the entire thrust belt from the eastern Altiplano to SA [Benjamin et al., 1987; Barnes et al., 2006; Gillis et al., 2006; McQuarrie et al., 2008]. In the south, initial late Eocene (36-40 Ma) exhumation began in the central EC, more distributed early Oligocene (27-33 Ma) exhumation throughout the EC and Altiplano continued until $\sim 20 \mathrm{Ma}$, IA exhumation occurred during the early to late Miocene $(\sim 9-18 \mathrm{Ma})$, and finally exhumation in the SA began in the late Miocene ( $\sim 8 \mathrm{Ma})$ [Ege et al., 2003; Scheuber et al., 2006; Ege et al., 2007].

\subsection{Thrust Belt Stratigraphy}

[9] The Paleozoic to Tertiary stratigraphy of the thrust belt including local thickness variations has been well documented throughout southern Bolivia and is synthesized in Figure 3. The Paleozoic section is locally thick in the EC and tapers toward the foreland [Sempere, 1995; Welsink et al., 1995]. A continuous succession of Ordovician through Devonian marine siliciclastic rocks is overlain by a discontinuous succession of nonmarine Carboniferous to Cretaceous rocks [Sempere, 1995; McQuarrie, 2002]. Compared to central and northern Bolivia, much greater pre-Jurassic erosion and much less Andean age erosion in this region has resulted in large exposures of Mesozoic rocks in the EC that rest directly and unconformably on the Silurian units (Figure 2) [McQuarrie and DeCelles, 2001]. Tertiary synorogenic sedimentary rocks reach local thicknesses of $\sim 12 \mathrm{~km}$ in the Altiplano, $\sim 2.5-5+\mathrm{km}$ in the EC, and $\sim 3-4 \mathrm{~km}$ in the SA [Sempere et al., 1990; Dunn et al., 1995; Kennan et al., 1995; Lamb and Hoke, 1997; McQuarrie and DeCelles, 2001; Horton, 2005; Uba et al., 2006].

\subsection{Thrust Belt Structure and Shortening}

[10] McQuarrie [2002] used field and geophysical observations to construct a balanced section across the fold-thrust belt at $\sim 19.5^{\circ} \mathrm{S}$ (Figure 2). Dominant structures exposed at the surface are $\sim 1$ - to $10-\mathrm{km}$-thick thrust sheets deforming the cover rocks. Individual thrust sheets in both the EC and IA are tightly folded and have minor offsets $(\sim 1-5 \mathrm{~km})$. The SA has multiple levels of detachments allowing for thrust sheets with larger $(\sim 5-15 \mathrm{~km})$ offsets that are less folded and hence more widely spaced. The balanced section indicates a total shortening of $326 \mathrm{~km}$ or $37 \%$ [McQuarrie, 2002]. More specifically, the EC has the highest magnitude of shortening of $122 \mathrm{~km}$ or $37 \%$, followed by the IA with 96 $\mathrm{km}$ or $63 \%$, and the SA with $67 \mathrm{~km}$ or $33 \%$.

[11] Although the geometry of the subsurface basement deformation is contentious, there is general agreement that large basement thrusts underlie the entire thrust belt except the SA which feed deformation into the overlying cover rocks [Kley, 1999; McQuarrie, 2002; Müller et al., 2002]. These large basement features, combined with small $(1-5 \mathrm{~km})$ offsets along individual surface faults, may provide a structural mechanism for potentially broad and uniform uplift and exhumation in the Altiplano, EC, and IA. In contrast, the SA have more widely spaced thrust sheets with larger individual offsets that are confined to the cover rocks thereby precluding such a structural mechanism for broad uplift.

\section{Methods}

[12] In this study, we integrate new apatite fission track samples from across the eastern Andean plateau flank at $\sim 19.5^{\circ} \mathrm{S}$ with the regional stratigraphy and a balanced cross section. Methods used in the regional stratigraphic compi-

Figure 2. Geology, balanced cross section, topography, and thermochronology data across the central Andean fold-thrust belt at $\sim 19.5^{\circ} \mathrm{S}$. The geology and cross section are simplified from McQuarrie [2002], and location is shown in Figure 1. BTB, back-thrust belt; FTB, fore-thrust belt. (a) Regional geology and sample locations. (b) Balanced cross section (location in Figure 2a) with samples projected onto the appropriate structures. (c) Transect profile of 80-km-wide swath-averaged mean topography with apatite (black dots) fission track pooled ages. Note the log scale for the ages. Error bars are $2 \sigma$. Zircon fission track ages (stars) are off the scale (shown by arrows) with actual values adjacent to the symbol. 


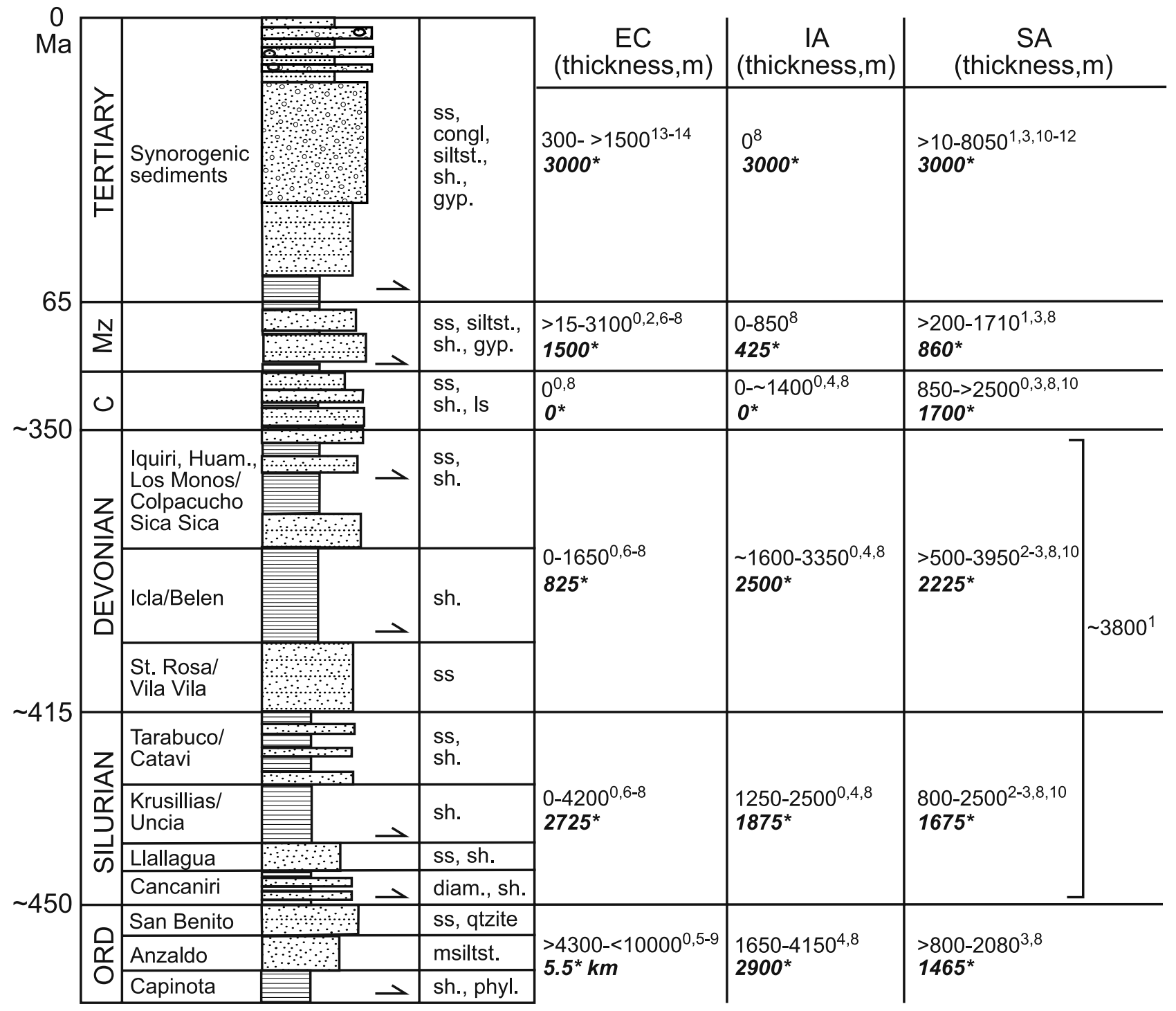

Figure 3. Regional stratigraphy and thickness variations of the central Andean fold-thrust belt in southern Bolivia (modified from Figure 2 of McQuarrie [2002]). Slashes delimit formation name changes from east to west, and arrows indicate major detachment horizons. Mz, Mesozoic; C, Carboniferous; Ord, Ordovician; Huam., Huamampampa; ss, sandstone; congl, conglomerate; siltst, siltstone; sh, shale; gyp, gypsum; ls, limestone; diam, diamictite; qtzite, quartzite; msiltst, metasiltstone; phyl, phyllite. Thickness constraints span from $\sim 18$ to $23^{\circ} \mathrm{S}$; Superscript numbers are the following sources: 0, Kley and Reinhardt [1994]; 1, Dunn et al. [1995]; 2, Sempere [1995]; 3, Moretti et al. [1996]; 4, Kley [1996]; 5, Kley et al. [1997]; 6, McQuarrie and DeCelles [2001]; 7, McQuarrie and Davis [2002]; 8, balanced/restored section from [McQuarrie [2002]; 9, Müller et al. [2002]; 10, Echavarria et al. [2003]; 11, Uba et al. [2006]; 12, Coudert et al. [1995]; 13, Horton [2005]; 14, Sempere et al. [1997]. Asterisk indicates the average thickness used in Figure 4 (see Appendix A for details).

lations and fission track analyses are outlined below and detailed in the Appendices.

\subsection{Regional Stratigraphy}

[13] We compiled regional stratigraphic sections across southern Bolivia $\left(\sim 18-23^{\circ} \mathrm{S}\right)$ to independently estimate the magnitude of exhumation by restoring the thermochronometer samples to original stratigraphic depth (Figure 3) (see details in Appendix A). Specifically, we constructed representative, regional sections measured from the range of thicknesses used in the balanced and restored section of McQuarrie [2002] because (1) it is the most proximal estimate that spans the entire study area, (2) its regional scale is most appropriate, and (3) the thickness variations themselves are derived from local field observations and supported by some of the compiled sections themselves [Dunn et al., 1995; Sempere, 1995; Gagnier et al., 1996; Kley, 1996; 


\section{EC BTB}

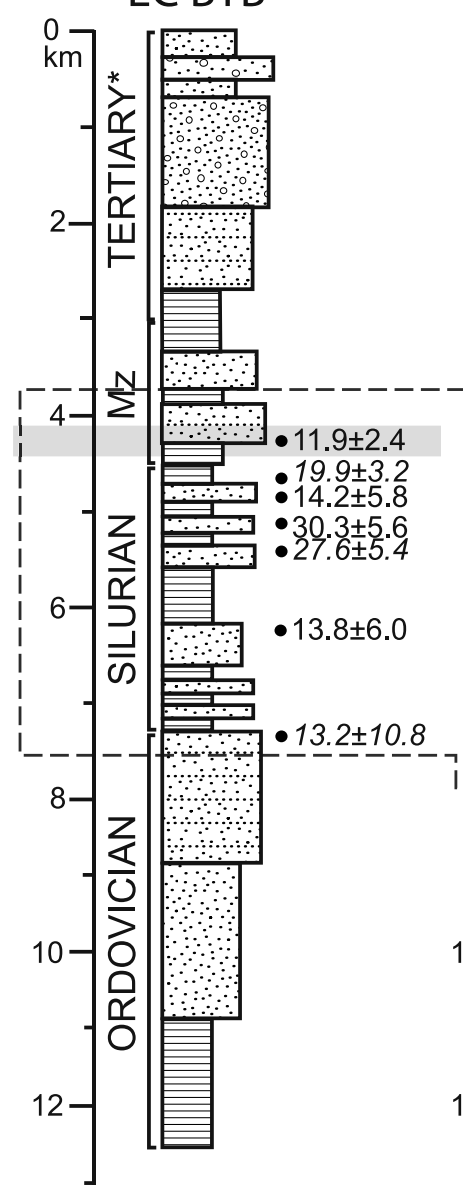

EC FTB

$\mathrm{km}$

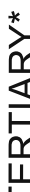

IA

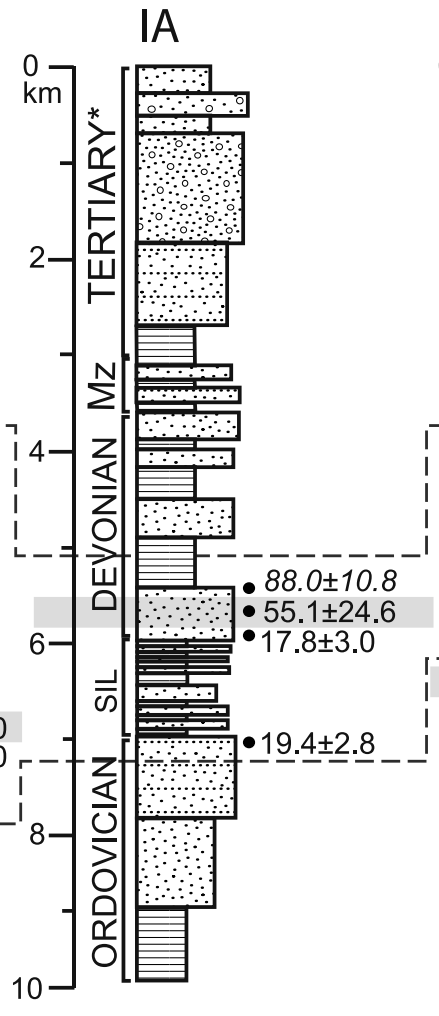

SA

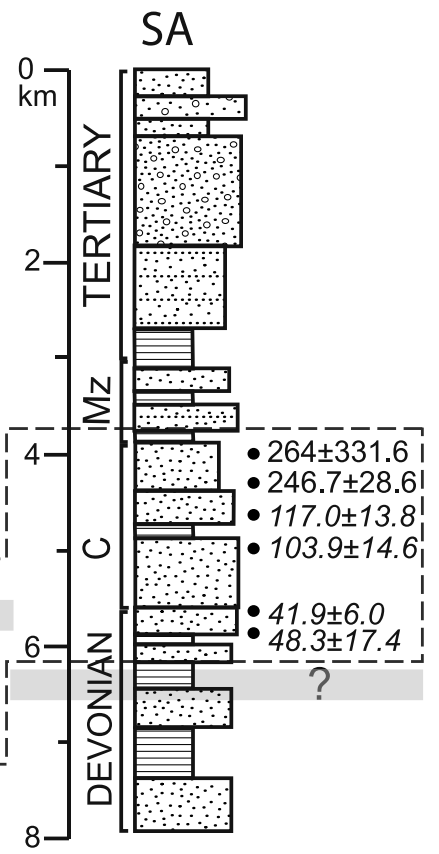

Figure 4. Apatite fission track (AFT) ages integrated within representative stratigraphy across the central Andean fold-thrust belt at $\sim 19.5^{\circ} \mathrm{S}$. Error associated with stratigraphic thickness and sample location is estimated to be $\sim 0.5 \mathrm{~km}$. Asterisk indicates that the Tertiary is assumed to have been there after DeCelles and Horton [2003]. Dv, Devonian; Sil, Silurian; additional abbreviations after Figures 1-3. Discordant samples in italics. Gray regions are estimated depth to full resetting of AFT samples as defined by the shallowest concordant AFT pooled age. Question-marked gray region is the inferred depth to fully reset and concordant AFT samples in the Subandes (see text for discussion). Dashed lines bracket the range of stratigraphic depths sampled in each zone. Lithologic thicknesses are schematic only after Figure 3.

Kley et al., 1997; Sempere et al., 1997; Horton et al., 2001; McQuarrie and DeCelles, 2001]. Our calculated average thicknesses are almost always within the compiled bounds (Figure 3). Figure 4 schematically shows these representative sections along with approximate sample locations.

[14] Stratigraphic thickness variations in the central Andean fold-thrust belt are large, but systematic (Figure 3). For example, the Ordovician thickens significantly southward along strike [McQuarrie and DeCelles, 2001; McQuarrie and Davis, 2002; Müller et al., 2002] and the Paleozoic section generally thins eastward from a local maximum in the central EC [Roeder and Chamberlain, 1995; Sempere, 1995; Welsink et al., 1995]. Despite these variations, it is useful to generalize the regional stratigraphy so that samples collected on numerous structures in a region can be interpreted together by evaluating them in the context of stratigraphic depth as a proxy for original depth prior to exhumation.

\subsection{Fission Track Thermochronology}

\subsubsection{General Background}

[15] Fission track thermochronology uses the accumulation of damage trails (fission tracks) that form from the spontaneous fission of ${ }^{238} \mathrm{U}$ in minerals to constrain sample thermal histories [e.g., Gallagher et al., 1998; Tagami and O'Sullivan, 2005]. Fission track ages are determined by measuring the parent $\left({ }^{238} \mathrm{U}\right) /$ daughter (tracks) ratios and determining the age from the rate of ${ }^{238} \mathrm{U}$ fission decay. Measured ages are cooling ages because the tracks are only quantitatively preserved above a particular closure temperature [Dodson, 1973], which is a function of mineral type, composition, and cooling rate. Fission tracks subsequently shorten (anneal) over a range of temperatures below the closure temperature. This temperature range is called the partial annealing zone (PAZ) [e.g., Hodges, 2003]. For common apatite, the closure temperature is $\sim 110 \pm 10^{\circ} \mathrm{C}$ 
and the PAZ spans from $\sim 60$ to $110^{\circ} \mathrm{C}$ [e.g., Gallagher et al., 1998]. For common zircon, the closure temperature is $\sim 240 \pm 10^{\circ} \mathrm{C}$ and the PAZ spans from $\sim 180$ to $240^{\circ} \mathrm{C}$ [Brandon et al., 1998].

[16] Cooling ages are commonly determined on $\sim 20-40$ individual grains resulting in a sample grain-age distribution. The sample pooled age is determined by the daughter/ parent ratio of all the grains summed ("pooled") together [e.g., Brandon, 1992]. A conventional $\chi^{2}$ test is applied to the sample grain-age distribution to determine its degree of variance. Concordant $\left(\mathrm{P}\left(\chi^{2}\right)>5 \%\right)$ samples have low age variance and their pooled age is considered geologically relevant [Galbraith, 1981; Green, 1981; Brandon et al., $1998]$. Conversely, discordant $\left(\mathrm{P}\left(\chi^{2}\right)<5 \%\right)$ samples, common for sedimentary rock samples, have significant age variance suggesting that (1) other mechanisms such as inhomogeneous uranium concentration and variable grainetching sensitivity are at work and/or (2) multiple component ages and variable thermal annealing from compositionally diverse grains exist that render the pooled age less meaningful [Green, 1981; Tagami and O'Sullivan, 2005]. Regardless of the age variance, measured ages and track length distributions are inverted for using empirically derived annealing algorithms [Ketcham, 2005 and references therein] to constrain permissible thermal histories.

\subsubsection{Analytical Procedures}

[17] The mineral separations and fission track analysis were performed using standard techniques (see Appendix B for details). In this study, most fission track ages reported were determined by the new laser ablation method (LAICPMS [Hasebe et al., 2004; Donelick et al., 2005]) with only a few ages determined by the more common external detector method (e.g., Gallagher et al., 1998). Following age analysis, the apatites were classified for annealing kinetics using the parameter Dpar [e.g., Burtner et al., 1994]. 3.2.3. Data Analysis and Thermal Modeling

[18] Methods for determining fission track component age populations within a discordant sample have been developed for data collected with the external detector method. BinomFit uses a deconvolution algorithm to identify statistically significant populations ages from a population of grain ages measured from a sample [Brandon, 2002].

[19] Inverse thermal modeling of the AFT data was performed with HeFTy [Ehlers et al., 2005; Ketcham, 2005] using the multikinetic annealing model of Ketcham et al. [1999] with c axis projected track lengths [Ketcham, 2003] (see details in Appendix C). We report the commonly used probability of a worse fit designations good $(0.5)$ and acceptable $(0.05)$ for the thermal history envelopes calculated with a Kuiper's statistical test [Press et al., 1992; Ketcham et al., 2000; Ketcham, 2005].

\section{Results}

\subsection{Overview}

[20] Twenty-three samples were analyzed from Cretaceous through Ordovician sandstones and quartzites exposed over $\sim 4 \mathrm{~km}$ in mean topographic relief from the eastern Altiplano through the Subandes at $\sim 19.5^{\circ} \mathrm{S}$
(Figure 2). Sample grain age and track length yields ranged from the maximum (40 ages and 200 track lengths/sample) to poor $(<10$ ages and/or track lengths/sample) with most (17 of 23) samples yielding robust results $(>10$ ages and track lengths/sample) (Table 1). The robust AFT pooled ages are Oligo-Miocene (14-30 Ma) in the EC, mostly early Miocene (18-20 Ma) in the IA, and mid-Eocene to Mesozoic (42-265 Ma) in the SA (Figure 2c and Table 1). Cooling histories inverted from this data are consistent with Eocene to recent cooling from temperatures of $\sim 65^{\circ} \mathrm{C}$ or greater. Consistently old, Paleozoic (385-471 Ma) ZFT pooled ages from the EC and IA indicate that the Tertiary cooling experienced by both regions has been limited to temperatures significantly $<240^{\circ} \mathrm{C}$ (Table 2 ). Representative stratigraphic sections independently suggest all samples were exhumed from variable depths of $\sim 3-8 \mathrm{~km}$ across the study region (Figure 4).

[21] All of the AFT pooled ages are younger than the sample depositional age and considered reset whereas the ZFT pooled ages range from reset to mostly detrital [after Brandon et al., 1998]. In detail, $100 \%$ of the individual AFT grain ages in the EC and IA samples are reset and 53-100\% of the grain ages in the SA samples are reset. Mean track lengths are short to long $(9.97-14.89 \mu \mathrm{m})$ with unimodel, bimodal, and/or skewed length distributions suggesting a wide range of cooling histories. AFT grain age and fission track Dpar values span 0.96-2.96 $\mu \mathrm{m}$. However, the majority of grains analyzed have Dpar values of $1-$ $1.75 \mu \mathrm{m}$ suggesting dominantly fast annealing calcianfluorapatite compositions [Donelick et al., 2005]. Despite the majority of grains lacking significant compositional variation, only 10 of the 23 sample pooled ages are concordant. The overdispersion of grain ages in the discordant samples is not conventionally attributable to composition [Carlson et al., 1999] because none of the samples exhibit correlations between Dpar and grain age or track length.

[22] Below, we detail (1) the modeling results of the AFT data from west to east across each zone mostly highlighting the good fit cooling histories with representative cooling envelopes shown in Figures 5-8 and (2) the ZFT pooled ages with $\pm 2 \sigma$ errors and associated interpretations.

\subsection{Altiplano}

[23] Our Altiplano sample (AL1) is from the Cretaceous El Molino formation west of Rio Mulato in the east vergent Rio Mulato fold belt (Figure 2 and Table 1) [McQuarrie and DeCelles, 2001]. Local age control for the El Molino is Maastrichtian to Danian (60 to $\sim 73 \mathrm{Ma}$ ) based on marine fossils and tuffs near the base [Sempere et al., 1997; Horton et al., 2001]. Given this, we assumed a depositional age of 60-80 Ma for the thermal history modeling. Sample AL1 acceptable fits suggest postdepositional burial to $\geq 80^{\circ} \mathrm{C}$ 40-60 Ma, followed by $>10 \mathrm{Ma}$ at PAZ temperatures of $\sim 70-85^{\circ} \mathrm{C}$ prior to rapid exhumation to the surface broadly constrained to start between 3 and $30 \mathrm{Ma}$ and end $0-15 \mathrm{Ma}$.

\subsection{Eastern Cordillera Back-Thrust Belt}

[24] We report seven samples (EC1-7) of Ordovician to Jurassic rocks exhumed from 4 to $7 \mathrm{~km}$ stratigraphic depths 

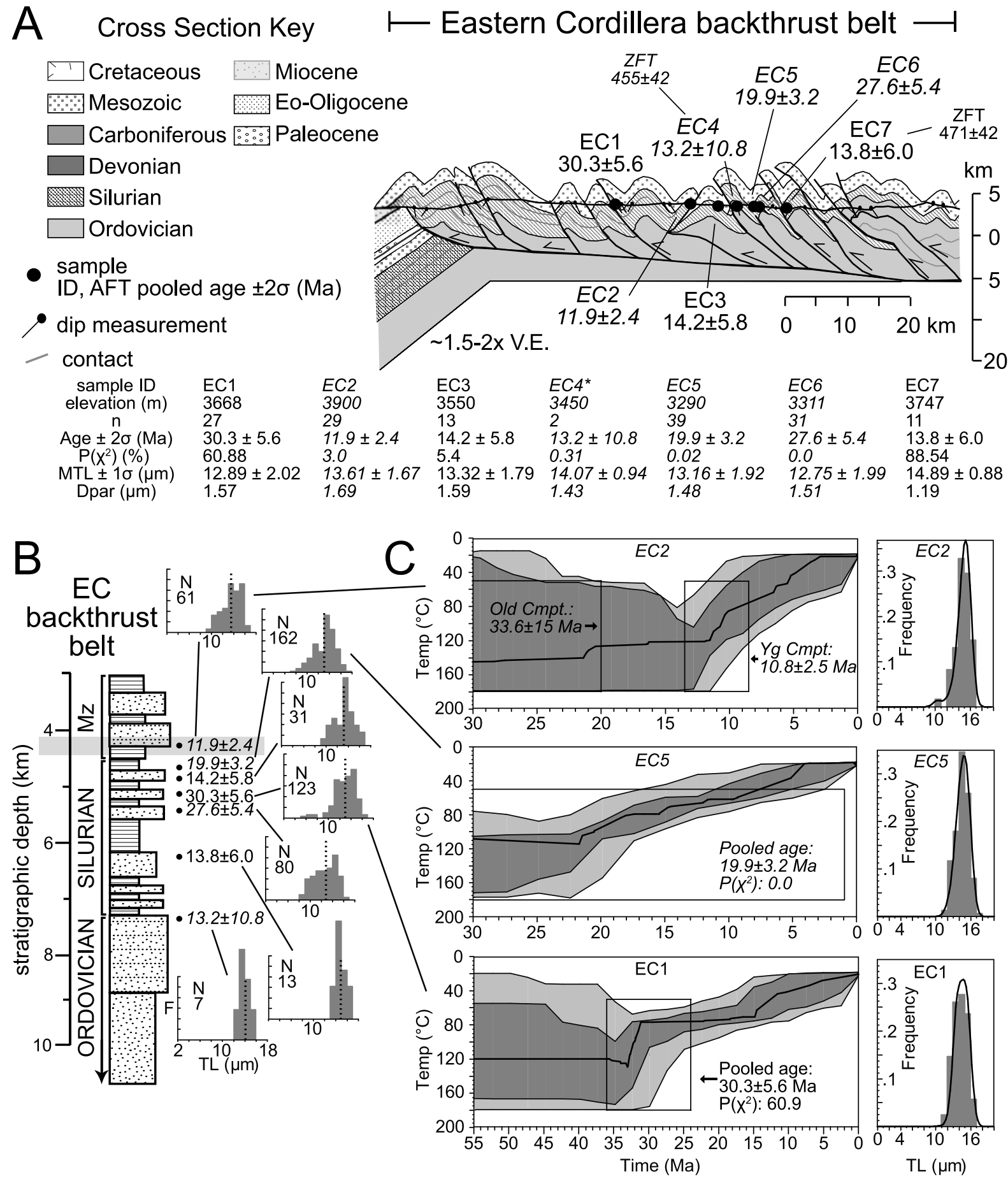

Figure 5. Eastern Cordillera (EC) back-thrust belt thermochronology data integrated with the regional structure and stratigraphy at $\sim 19.5^{\circ} \mathrm{S}$. (a) Cross section from McQuarrie [2002] with samples projected onto the appropriate structures. AFT, apatite fission track; ZFT, zircon fission track pooled age and $2 \sigma$ (Ma) where available. VE, vertical exaggeration. Discordant samples are in italics. Summary table of selected AFT data is directly below (see Table 1 for all data and abbreviations). (b) AFT pooled age (Ma) and track length data in their regional stratigraphic context from Figure 4. Track length distribution histograms uncorrected to c axis parallel; F, frequency; N, number of tracks measured, and mean track length (dashed line). (c) Selected thermal modeling results showing acceptable (light gray), good (dark), and best (thick line) fit cooling histories inverted from the AFT data. Boxes are modeling constraints. Old Cmpt, old age component; Yg Cmpt, young component age. Track length (TL) distribution (c axis parallel) shown for the data (bars) and best fit (line) model. 
A Cross Section Key

$\square$ Cretaceous

Mesozoic

$\square$ Carboniferous

Devonian

Silurian

Ordovician

AFT sample

ID, pooled age $\pm 2 \sigma(\mathrm{Ma})$

dip measurement

- contact

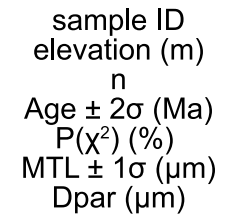

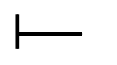

Eastern Cordillera forethrust belt Break

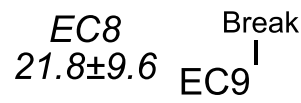

$61.6 \pm 53.0$

EC11

EC10 26.9 2 4.2

EC12

$35.6 \pm 17.0$

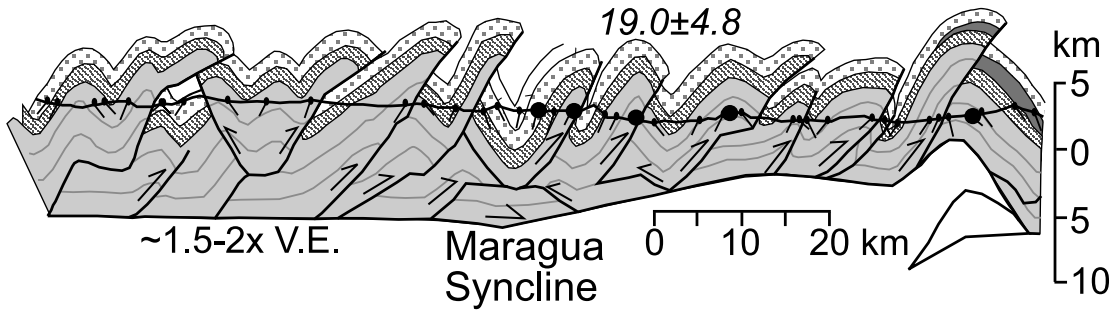

$\begin{array}{lllll}E C 8^{*} & E^{*} 9^{*} & E C 10 & E C 11 & \text { EC12* } \\ 3156 & 3253 & 3222 & 2255 & 3065 \\ 8 & 4 & 18 & 36 & 7 \\ 21.8 \pm 9.6 & 61.6 \pm 53.0 & 19.0 \pm 4.8 & 26.9 \pm 4.2 & 35.6 \pm 17.0 \\ 3.85 & 96.83 & 0.73 & 0.0 & 16.89 \\ 14.47 \pm 2.25 & 11.64 \pm 1.27 & 13.95 \pm 1.37 & 13.49 \pm 1.77 & 12.83 \pm 1.09 \\ 1.43 & 1.9 & 1.42 & 2.02 & 1.56\end{array}$

\section{B EC forethrust belt}

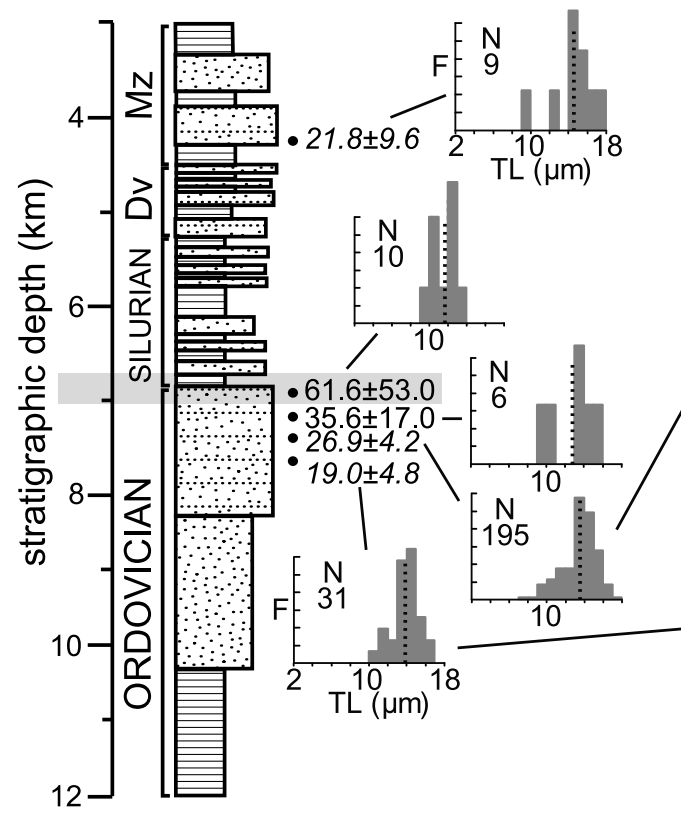

C

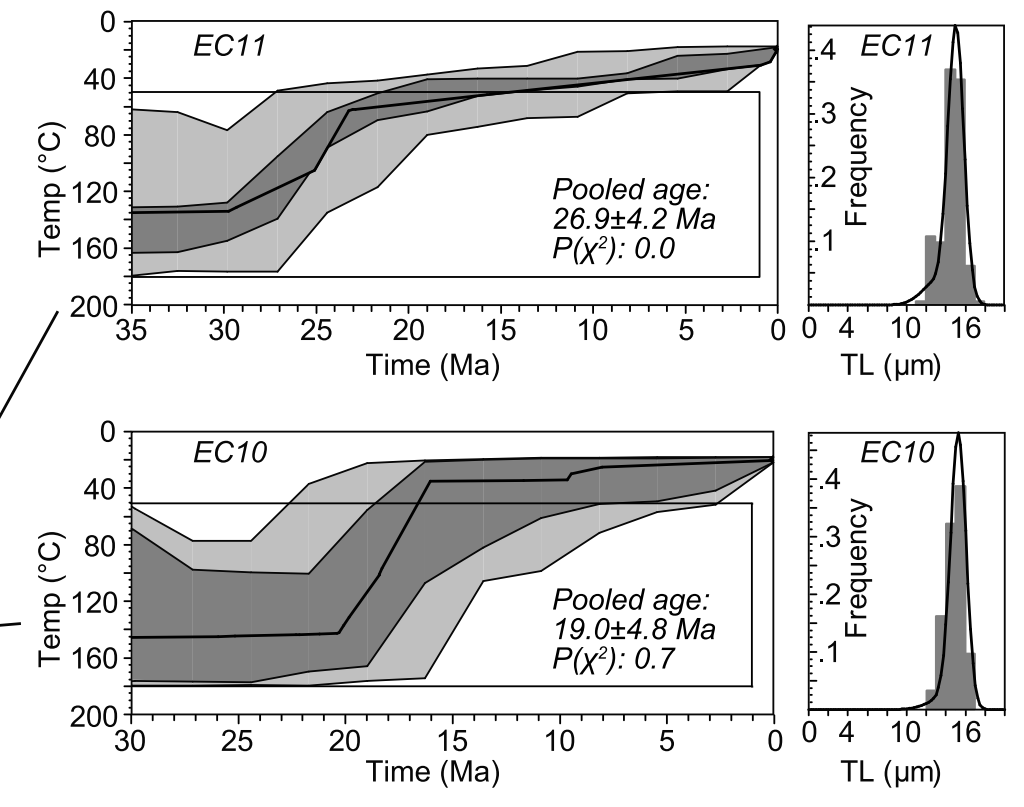

Figure 6. Eastern Cordillera (EC) fore-thrust belt thermochronology data integrated with the regional structure and stratigraphy at $\sim 19.5^{\circ} \mathrm{S}$. See Figure 5 caption for details.

across four different thrust sheets in the EC back-thrust belt (Figure 5). Concordant sample EC1 modeling constrains good fit cooling from $\geq \sim 100^{\circ} \mathrm{C} 32-35 \mathrm{Ma}$, followed by slow cooling through the PAZ until $\sim 15 \mathrm{Ma}$, and ultimately more rapid cooling until $\sim 0-10 \mathrm{Ma}$ (Figure $5 \mathrm{c}$ ). Discordant sample EC2 has two deconvolved component ages of 10.8 and 33.6 Ma (Table 1). Good fit model results show EC3 cooling began most recently $\sim 13 \mathrm{Ma}$ from $\geq \sim 105^{\circ} \mathrm{C}$ (Figure $5 \mathrm{c}$ ). We note these results are nearly identical to those obtained with only a fixed $50-180^{\circ} \mathrm{C}$ constraint equal in age to between deposition and $1 \mathrm{Ma}$ as most discordant samples are reported in this study. Model results of concor- dant sample EC3 demarcate acceptable cooling beginning $10-15 \mathrm{Ma}$ from $\geq \sim 90^{\circ} \mathrm{C}$ with good fits refining initial cooling to $\sim 15 \mathrm{Ma}$ from $\geq \sim 105^{\circ} \mathrm{C}$.

[25] Samples EC4-EC6 project onto the same structure implying their cooling histories should be related (Figure 5). However, they overlie a blind thrust that may have imparted different kinematic histories and thus we report their cooling histories independently. Sample EC4 has poor data quality with acceptable rapid cooling from $\geq 90^{\circ} \mathrm{C}$ at $>5 \mathrm{Ma}$ with good fits constraining rapid cooling from $\geq 105^{\circ} \mathrm{C} 11$ $16 \mathrm{Ma}$. Good fit modeling results for discordant sample EC5 suggests rapid cooling started from $\geq 105^{\circ} \mathrm{C}$ at $20-25$ 
A Cross Section Key

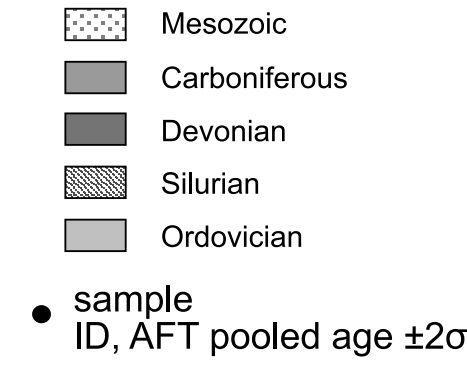

dip measurement

- contact

$\vdash$ Interandean zone (IA) -

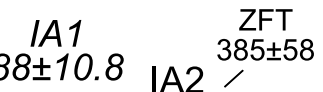
$19.4 \pm 2.8$

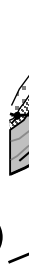

.

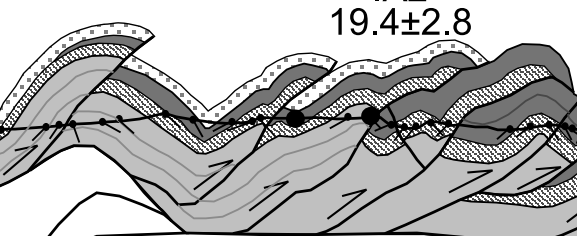

Tarabuco

Syncline

$\sim 1.5-2 x$ V.E.
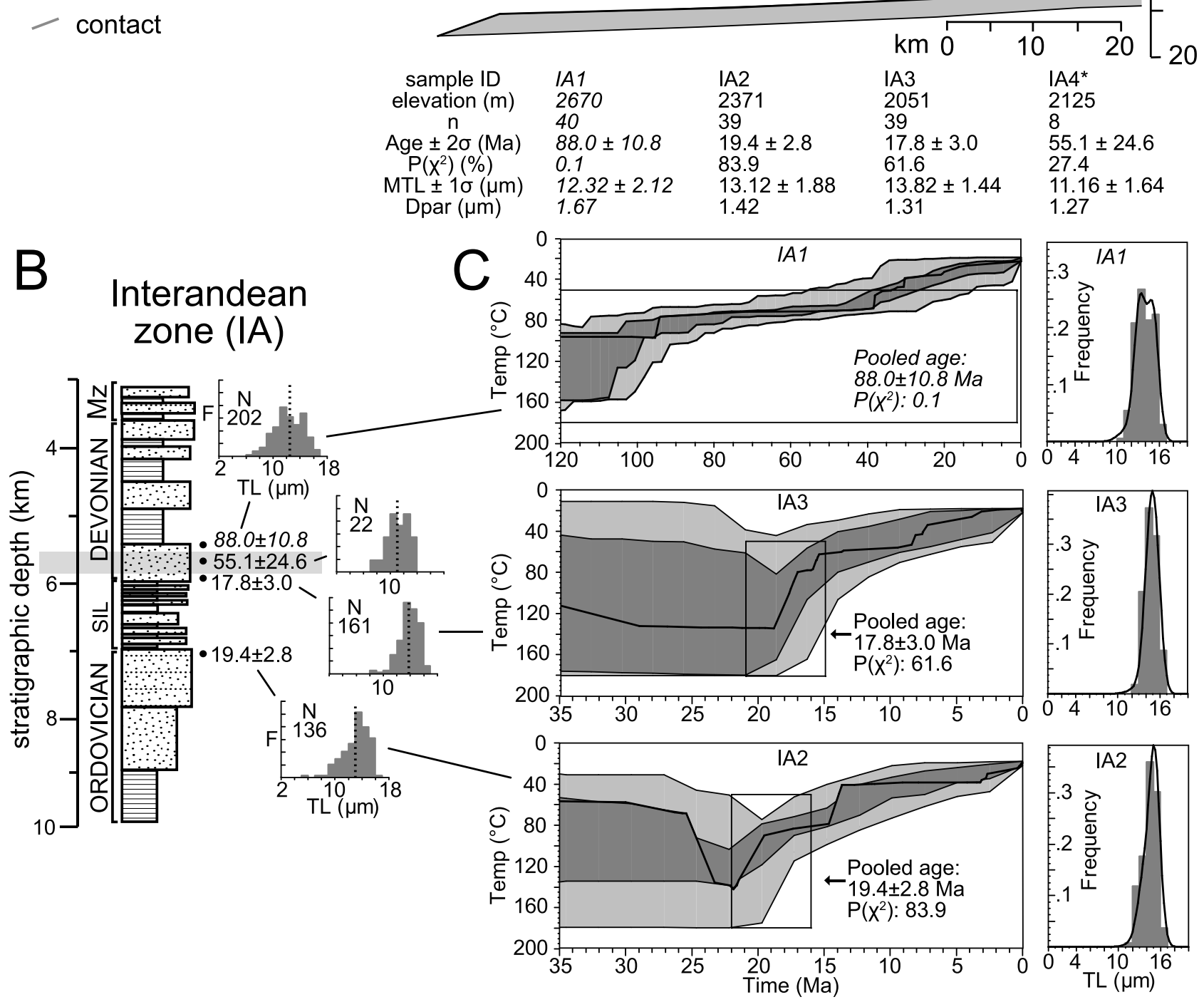

Figure 7. Interandean zone (IA) thermochronology data integrated with the regional structure and stratigraphy at $\sim 19.5^{\circ} \mathrm{S}$. See Figure 5 caption for details.

Ma (Figure 5c). For sample EC6, model results define acceptable rapid cooling from $\geq 100^{\circ} \mathrm{C} 29-39$ Ma with good fits constraining initial cooling from $\geq 105^{\circ} \mathrm{C} 34-$ $36 \mathrm{Ma}$. Finally, concordant sample EC7 modeling delimits rapid cooling from $\geq 105^{\circ} \mathrm{C} 10-20 \mathrm{Ma}$.
[26] We also report two ZFT results from samples EC4 and EC7 (Figure 5a and Table 2). EC4 was exhumed from the greatest stratigraphic depths in the EC of $>7 \mathrm{~km}$ and has a discordant ZFT pooled age of $455 \pm 42 \mathrm{Ma}$ which is equivalent to the Devonian depositional age (Figure 5a). We 
Cross Section Key

$\square$ Mesozoic
$\square$ Carboniferous
$\square$ Devonian
$\square$ Silurian
$\square$ Ordovician

- AFT sample

ID, pooled age $\pm 2 \sigma(\mathrm{Ma})$

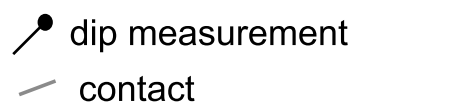

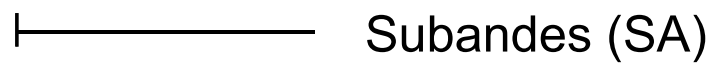

SA3

$264.3 \pm 32$

SA4

SA1

$\begin{array}{cc}\text { 48.3 } 3 \text { +17.4 } & \text { SA2 } \\ & 41.9 \pm 6\end{array}$

$117 \pm 14$

SA5

$103.9 \pm 15$

SA6

$246.7 \pm 29$

$\mathrm{km}$

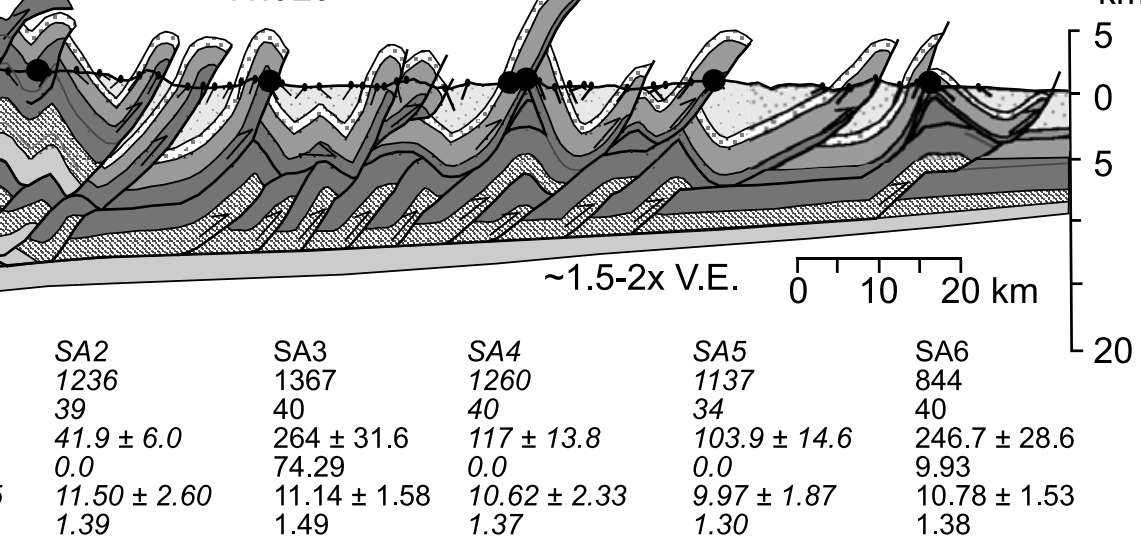

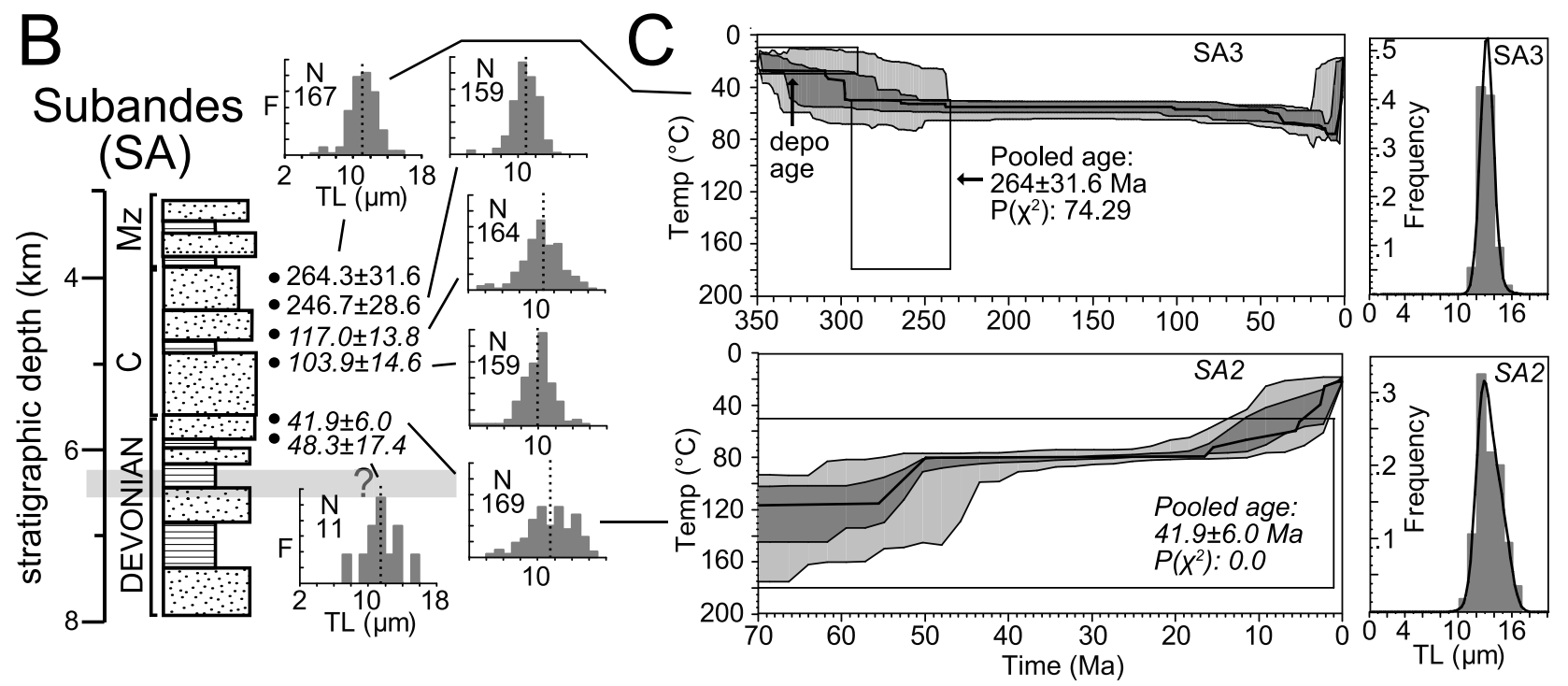

Figure 8. Subandes (SA) thermochronology data integrated with the regional structure and stratigraphy at $\sim 19.5^{\circ} \mathrm{S}$. See Figure 5 caption for details. Depo age, deposition age.

consider this ZFT sample unreset and probably detrital. EC7 has a discordant ZFT pooled age of $471 \pm 42 \mathrm{Ma}$ which is older than the Silurian depositional age and considered detrital.

[27] Collectively, the EC back-thrust belt samples were exhumed from 4 to $7 \mathrm{~km}$ stratigraphic depths and record three phases of rapid AFT cooling that started in the (1) late Eocene (32-36 Ma; EC1 and EC6), (2) late Oligocene to early Miocene (20-25 Ma; EC5), and (3) middle to late Miocene ( $11-$ $16 \mathrm{Ma}$; EC2-4 and EC7). Two detrital Paleozoic ZFT ages indicate regional Tertiary cooling has been limited to temperatures significantly $<240^{\circ} \mathrm{C}$.

\subsection{Eastern Cordillera Fore-Thrust Belt}

[28] We report five samples (EC8-12) of Ordovician to Jurassic rocks exhumed from 4 to $8 \mathrm{~km}$ stratigraphic depths across four different thrust sheets in the EC fore-thrust belt (Figure 6). Acceptable modeling results for discordant sample EC8 suggest recent cooling began $>14$ Ma from $\geq \sim 100^{\circ} \mathrm{C}$ with good fits constraining initial cooling from 21 to $25 \mathrm{Ma}$. Concordant sample EC9 good fit modeling results define cooling from PAZ temperatures of $65-80^{\circ} \mathrm{C}$ 4-40 Ma. The most likely cooling history for samples EC8 and EC9 must be defined by where the sample cooling envelopes overlap because they are structurally linked. In this case, EC9 probably cooled rapidly from $\sim 21-25 \mathrm{Ma}$ as did EC8. Discordant sample EC10 good fit modeling results constrain recent cooling from $\geq 100^{\circ} \mathrm{C} 19-22 \mathrm{Ma}$ (Figure 6c). Acceptable modeling fits for sample EC11 constrain rapid cooling at $27-30 \mathrm{Ma}$ from $\geq 75^{\circ} \mathrm{C}$ with good fits refining cooling from $\geq 125^{\circ} \mathrm{C} \quad 27-30 \mathrm{Ma}$ 


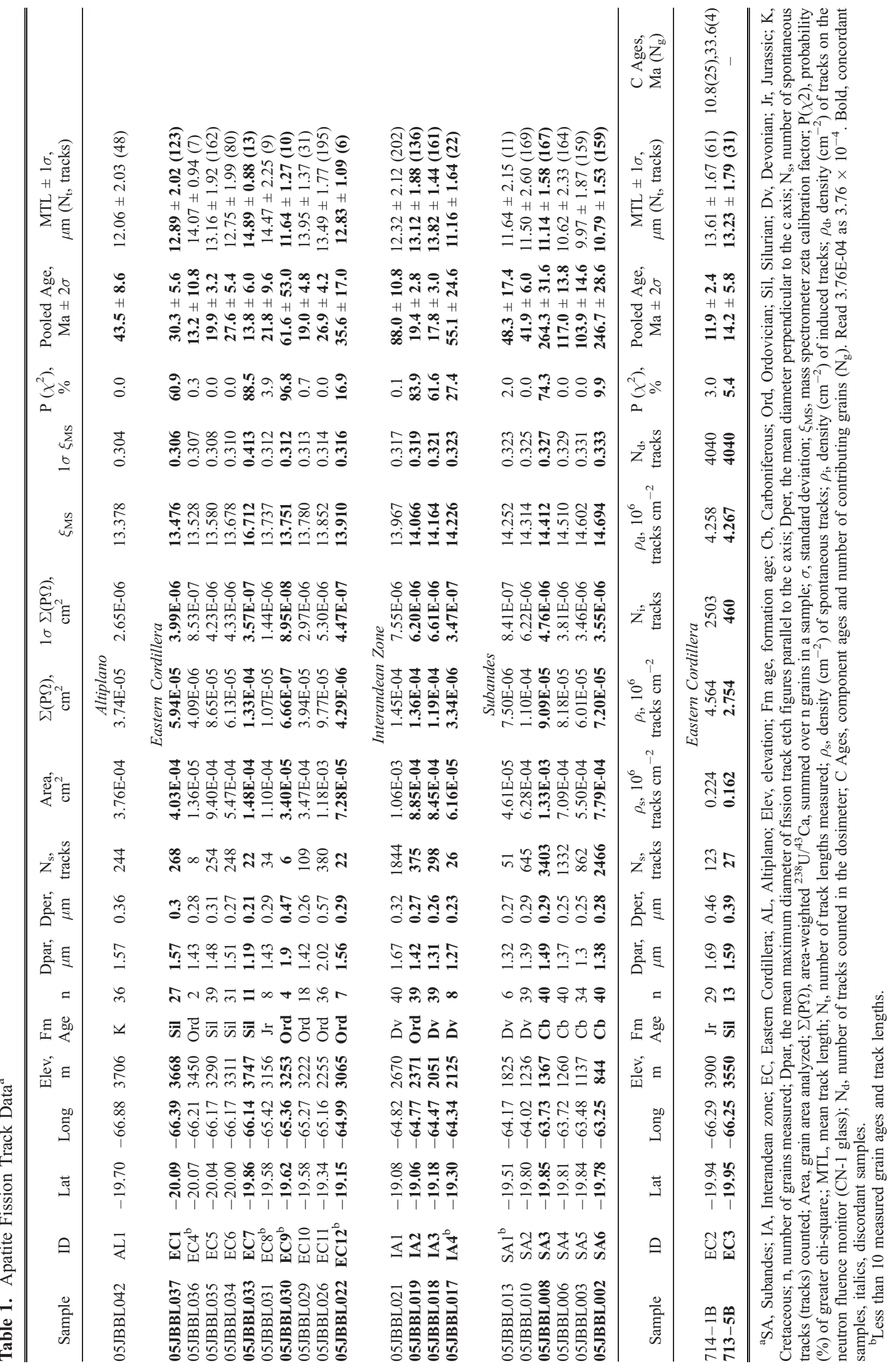


Table 2. Zircon Fission Track Data ${ }^{a}$

\begin{tabular}{|c|c|c|c|c|c|c|c|c|c|c|c|c|c|c|}
\hline Sample & ID & Lat & Long & $\begin{array}{c}\text { Elev, } \\
\mathrm{m}\end{array}$ & $\begin{array}{l}\text { Fm } \\
\text { Age }\end{array}$ & $\mathrm{n}$ & $\begin{array}{l}\mathrm{N}_{\mathrm{s}} \\
\text { tracks }\end{array}$ & $\begin{array}{l}\text { Area, } \\
\mathrm{cm}^{2}\end{array}$ & $\begin{array}{c}\Sigma(\mathrm{P} \Omega), \\
\mathrm{cm}^{2}\end{array}$ & $\begin{array}{c}1 \sigma(\mathrm{P} \Omega) \\
\mathrm{cm}^{2}\end{array}$ & $\xi_{\mathrm{MS}}$ & $1 \sigma \xi_{\mathrm{MS}}$ & $\begin{array}{c}\mathrm{P}\left(\chi^{2}\right), \\
\%\end{array}$ & $\begin{array}{l}\text { Pooled Age, } \\
\quad \operatorname{Ma} \pm 2 \sigma\end{array}$ \\
\hline \multicolumn{15}{|c|}{ Eastern Cordillera } \\
\hline 05JBBL036 & $\mathrm{EC} 4$ & -20.07 & -66.21 & 3450 & Ord & 20 & 2306 & $6.46 \mathrm{E}-05$ & $1.40 \mathrm{E}-05$ & $1.86 \mathrm{E}-07$ & 5.736 & 0.222 & 0.0 & $455 \pm 42$ \\
\hline 05JBBL033 & EC7 & -19.86 & -66.14 & 3747 & Sil & 20 & 2941 & 8.64E-05 & $1.71 \mathrm{E}-05$ & $2.37 \mathrm{E}-07$ & 5.692 & 0.220 & 0.0 & $471 \pm 42$ \\
\hline \multicolumn{15}{|c|}{ Interandean zone } \\
\hline 05JBBL019 & $\mathrm{IA} 2^{\mathrm{b}}$ & -19.06 & -64.77 & 2371 & Ord & 6 & 645 & $2.04 \mathrm{E}-05$ & $4.67 \mathrm{E}-06$ & $2.33 \mathrm{E}-07$ & 5.751 & 0.223 & 0.0 & $385 \pm 58$ \\
\hline 05JBBL018 & IA3 & -19.18 & -64.47 & 2051 & Dv & 20 & 2947 & $9.08 \mathrm{E}-05$ & $2.00 \mathrm{E}-05$ & $2.89 \mathrm{E}-07$ & 5.765 & 0.224 & 0.0 & $411 \pm 38$ \\
\hline
\end{tabular}

${ }^{\mathrm{a}}$ Abbreviations and symbols same as in Table 1 .

${ }^{\mathrm{b}}$ Less than 10 measured grain ages and track lengths.

(Figure 6c). Sample EC12 acceptable modeling fits suggest recent cooling by $>20 \mathrm{Ma}$ from $\geq 85^{\circ} \mathrm{C}$ with good fits refining cooling from $\geq 95^{\circ} \mathrm{C}$ more than $22 \mathrm{Ma}$.

[29] Collectively, the EC fore-thrust belt samples were exhumed from the greatest stratigraphic depths of mostly $\geq 7 \mathrm{~km}$ and record two phases of rapid AFT cooling that started in the (1) early Oligocene (27-30 Ma; EC11; maybe EC12) and (2) early Miocene (19-25 Ma; EC8-10, maybe EC12).

\subsection{Interandean Zone}

[30] We report four samples (IA1-4) from Ordovician to Devonian rocks exhumed from 5 to $7 \mathrm{~km}$ stratigraphic depths across two different thrust sheets in the IA (Figure 7). Sample IA1 modeling results infer initial cooling began $\sim 100 \mathrm{Ma}$ from $\geq \sim 80^{\circ} \mathrm{C}$, followed by residence in the PAZ until a final episode of more rapid cooling to the present from at most $\sim 40 \mathrm{Ma}$ (Figure $7 \mathrm{c}$ ). Sample IA2 modeling results delimit recent cooling beginning 20-22 Ma from $\geq \sim 100^{\circ} \mathrm{C}$ (Figure $7 \mathrm{c}$ ). Taken together, these two samples are consistent with rapid cooling starting 20-22 Ma and best represented by the results from IA2. Good fit thermal envelopes for sample IA3 demarcate cooling from temperatures $\geq \sim 90^{\circ} \mathrm{C}$ beginning $19-21$ Ma (Figure 7c). For sample IA4, modeling results imply initial cooling began $\geq \sim 40 \mathrm{Ma}$ from $\geq \sim 100^{\circ} \mathrm{C}$, followed by residence in PAZ temperatures of $55-80^{\circ} \mathrm{C}$ until a final episode of more rapid acceptable cooling initiated from 3 to $20 \mathrm{Ma}$ with good fits limiting final rapid cooling from 3 to $10 \mathrm{Ma}$.

[31] We also report two ZFT results from samples IA2 and IA3 (Figure 7a and Table 2). IA2 was exhumed from the greatest stratigraphic depths in the IA of $\sim 7 \mathrm{~km}$ and has a discordant ZFT pooled age of $385 \pm 58 \mathrm{Ma}$, but low grain yield. The ZFT pooled age is younger than the Ordovician depositional age and hence considered reset, but not by the Cenozoic Andean orogeny. IA3 has a discordant ZFT pooled age of $411 \pm 38 \mathrm{Ma}$ which is equivalent to the Devonian depositional age. We consider this ZFT sample unreset and probably detrital.

[32] Collectively, the IA samples were exhumed from 5 to $7 \mathrm{~km}$ stratigraphic depths and record mostly rapid AFT cooling starting in the early Miocene (19-22 Ma; IA1-3). This early Miocene cooling is roughly uniform across most of the IA. Sample IA4 shows late Miocene or younger (3-
$10 \mathrm{Ma})$ initial cooling from the PAZ. Two reset and unreset Paleozoic ZFT ages indicate local Tertiary cooling has been limited to temperatures significantly $<240^{\circ} \mathrm{C}$ in the IA.

\subsection{Subandes}

[33] We report six samples (SA1-6) from Devonian to Carboniferous rocks exhumed from 4 to $6 \mathrm{~km}$ stratigraphic depths across five different thrust sheets in the SA (Figure 8). Acceptable modeling results for sample SA1 suggest recent cooling began from PAZ temperatures of $<90^{\circ} \mathrm{C} \mathrm{3-30} \mathrm{Ma} \mathrm{with} \mathrm{good} \mathrm{fits} \mathrm{refining} \mathrm{cooling} \mathrm{from} 60$ to $85^{\circ} \mathrm{C} 3-30 \mathrm{Ma}$. Discordant sample SA2 modeling implies cooling began $\sim 50$ Ma from $\geq \sim 100^{\circ} \mathrm{C}$, followed by residence in the PAZ until more recent cooling began $\sim 8-20 \mathrm{Ma}$ from $\sim 80^{\circ} \mathrm{C}$ (Figure $8 \mathrm{c}$ ). Concordant sample SA3 good fits imply significant residence in PAZ temperatures of $\sim 75^{\circ} \mathrm{C}$ until recent, rapid cooling began $\sim 3-$ $8 \mathrm{Ma}$ (Figure 8c). For sample SA4, modeling suggests significant residence in PAZ temperatures of $\sim 70-75^{\circ} \mathrm{C}$ until recent, rapid cooling began $4-23$ Ma (acceptable fits) or 7-13 Ma (good fits) from $75^{\circ} \mathrm{C}$. As part of the same thrust sheet, samples SA3 and SA4 probably cooled beginning 4-20 Ma (overlapping acceptable fits) or 7-8 Ma (overlapping good fits). Unfortunately, modeling did not produce any acceptable cooling histories for sample SA5. On the basis of similarities in stratigraphic position, lithology, and AFT data, we assume a cooling history similar to SA4. Finally, modeling of sample SA6 suggests significant residence in PAZ temperatures of $\sim 65^{\circ} \mathrm{C}$ until acceptable recent, rapid cooling began $2-19 \mathrm{Ma}$ with good fits refining that to 2-8 Ma.

[34] Collectively, the SA samples were exhumed from 4 to $6 \mathrm{~km}$ stratigraphic depths and record Miocene to Pliocene initial cooling ( 3-20 Ma; SA1-6). Oligo-Miocene cooling ( 10-30 Ma; SA1-2) began in the west, stepping eastward to late Miocene ( 7-8 Ma; SA3-4) and eventually as young as Pliocene (2-8 Ma; SA6) in the easternmost structure (Figure 8). One additional observation is that the SA samples show a systematic decrease in age with stratigraphic depth from concordant late Paleozoic to earliest Mesozoic pooled ages exhumed from $\sim 4 \mathrm{~km}$ depths to discordant mid-Eocene ages exhumed from $\sim 5.5 \mathrm{~km}$ depths (Figure 8). Several Devonian to Tertiary exposures previ- 

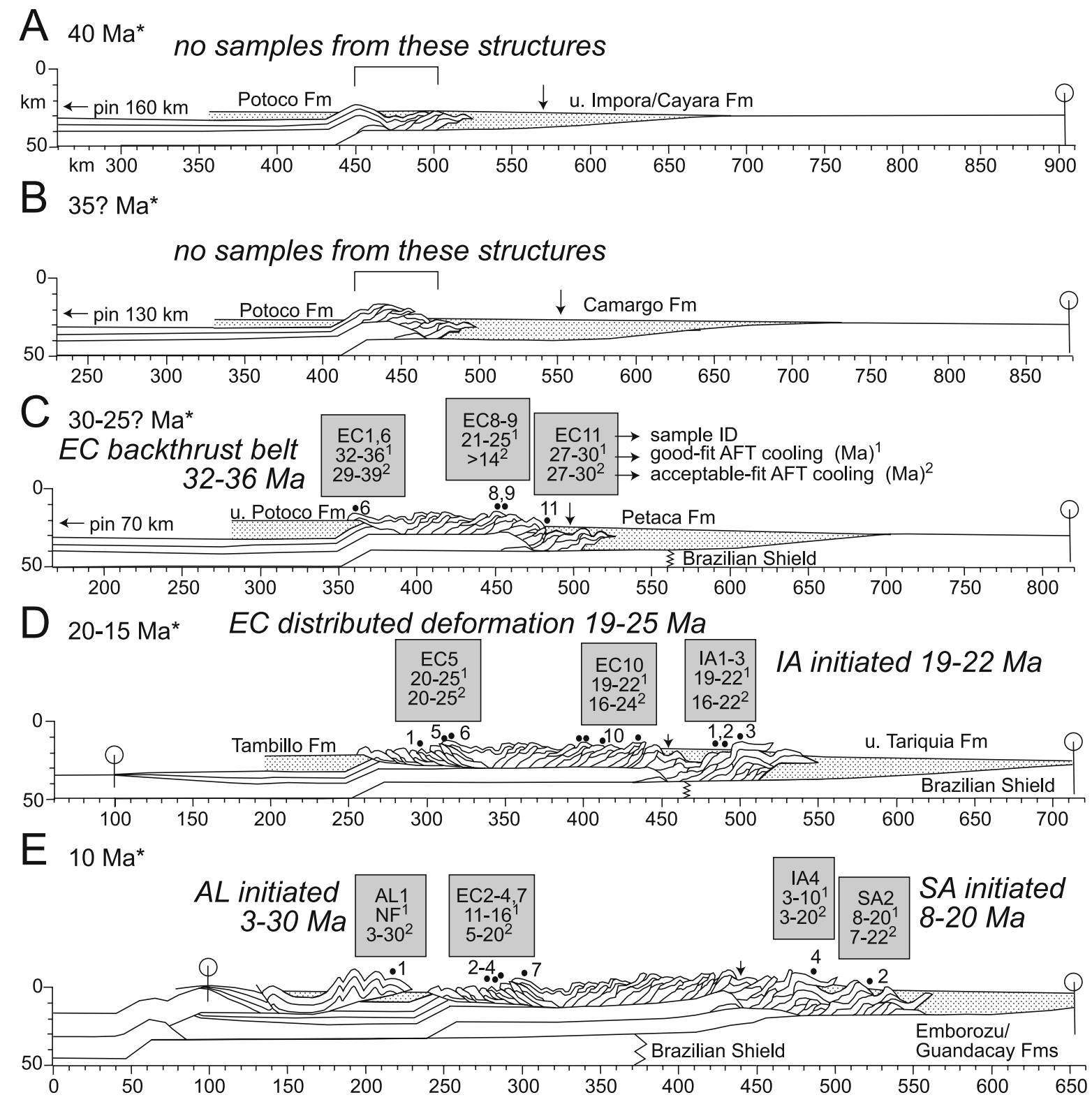

$\mathrm{F}_{0 \mathrm{Ma}}$

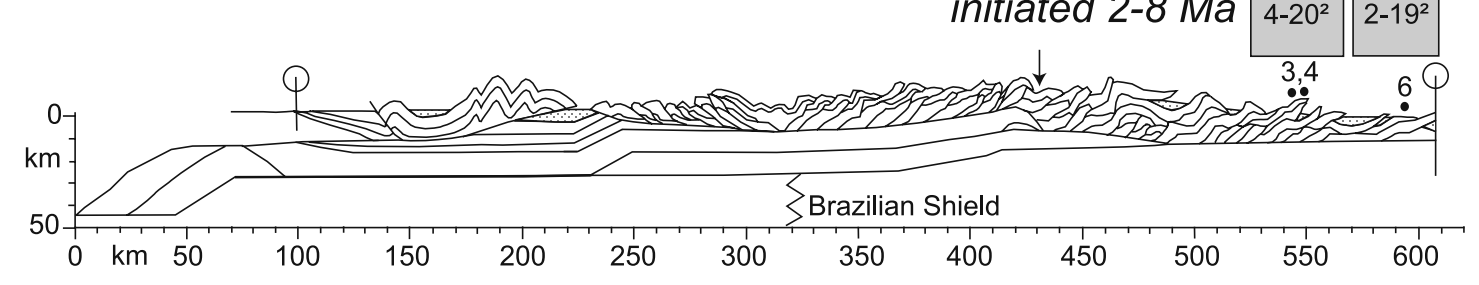

Figure 9. Chronology of deformation and exhumation across the eastern flank of the central Andean plateau at $\sim 19.5^{\circ} \mathrm{S}$. Previous chronologic estimates $\left(\mathrm{Ma}^{*}\right)$ and sequential kinematic reconstruction with foreland basin deposits are from McQuarrie et al. [2005]. This previous chronology is based on an integration of published structural, stratigraphic, and thermochronologic data in Bolivia. Grey boxes indicate a revised chronology based on the thermochronometer data presented in this paper. Grey box text indicates sample $\operatorname{ID(s)}$ (top row) and the age of initial rapid cooling (in Ma) from good (1) and acceptable (2) thermal modeling results. Black dots are samples with ID number. Major exhumation and deformation episodes are highlighted with italicized text. NF, no fits. Arrow is eastern edge of the Andean plateau/Tarabuco and Incapampa syclines (see Figure 2 for location), and jagged line is the western edge of the Brazilian shield. 

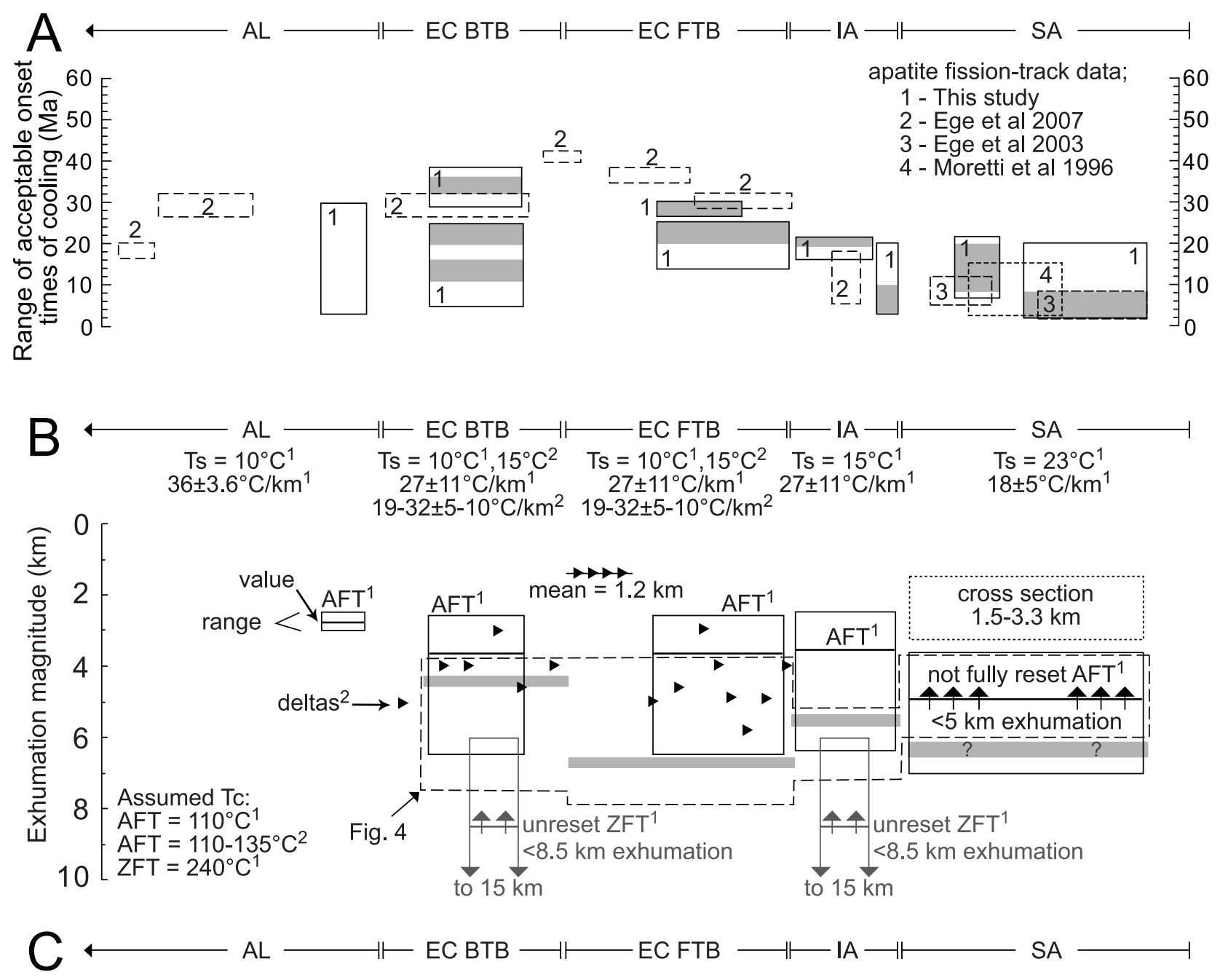

simplified cross section at $\sim 19.5^{\circ} \mathrm{S}$

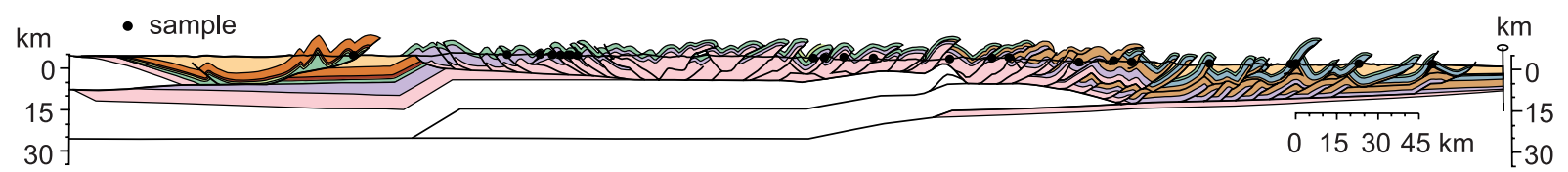

Figure 10. Thermochronologic constraints on the exhumation history across the central Andean foldthrust belt at $19.5-21.5^{\circ} \mathrm{S}$. AL, Altiplano; BTB, back-thrust belt; FTB, fore-thrust belt. (A) Distribution of recorded rapid cooling episodes inferred from apatite fission track (AFT) data compiled from this study and others. See legend for appropriate references. Range of acceptable (open boxes) and good (gray boxes) fits from inverse modeling of the AFT data for the onset of rapid cooling for this study as well as summary results (dashed boxes) from Ege et al. [2007, Figure 12], Ege et al. [2003, Figure 2], and Moretti et al. [1996, p. 24]. (b) Estimated exhumation magnitudes. Assumed surface temperature (Ts) and geothermal gradients necessary to quantify these estimates are listed at the top of each region. Assumed closure temperatures $(\mathrm{Tc})$ for the different thermochronometer systems are listed in the bottom left corner. Abbreviations and references are the same as in Figure 10a. Black deltas are from Ege et al. [2007, Figure 13]. ZFT, zircon fission track. Vertical arrows indicate an upper limit due to not fully reset cooling ages. Dashed lines are estimated from the representative stratigraphy with gray bars as estimated (or inferred with question marks) depth to fully reset and concordant AFT samples from Figure 4. Dotted box in the SA is the most likely estimate from the cross section for the SA where depth to AFT closure represents a maximum because the cooling ages are not fully reset. (c) Cross section same as in Figure $2 \mathrm{~b}$. 
Table 3. Shortening Rates for the Central Andean Fold-Thrust Belt $\left(\sim 19.5^{\circ} \mathrm{S}\right)$, Southern Bolivia

\begin{tabular}{llcll}
\hline Location & Amount, $\mathrm{km}$ & Time Interval, ${ }^{\mathrm{a}} \mathrm{Ma}$ & Rate, mm/a & Time Interval, Ma \\
\hline WC to EC & $200-250^{\mathrm{a}}$ & $45-70$ & $8-10^{\mathrm{a}}$ & - \\
EC and IA & $218^{\mathrm{b}}$ & $40-15 / 20$ & $8.5-11^{\mathrm{a}}$ & 40 to $10-20$ \\
SA & $67^{\mathrm{b}}$ & $15 / 20-0 ?$ & $3.5-4.5$ & $20-0^{\mathrm{c}}$ \\
SA & $67^{\mathrm{b}}$ & - & - & $8-0^{\mathrm{d}}$ \\
Total & $550^{\mathrm{a}}$ & $70-0$ & $7.8^{\mathrm{a}}$ & - \\
\hline
\end{tabular}

${ }^{\mathrm{a}}$ From McQuarrie et al. [2005].

${ }^{\mathrm{b}}$ From McQuarrie [2002].

${ }^{\mathrm{c}}$ Assuming oldest modeling good fit of sample SA2 represents initiation of deformation.

${ }^{\mathrm{d}}$ Assuming youngest modeling good fit of sample SA2 represents initiation of deformation.

ously analyzed along this transect also have Mesozoic to early Tertiary AFT ages [Moretti et al., 1996].

\section{Discussion}

\subsection{Erosional Cooling of Thermochronometer Data}

[35] In active orogens, thermochronometer cooling can result from erosional exhumation, tectonic exhumation along normal faults, magmatism, and/or fluid flow [Ring et al., 1999; Ehlers, 2005]. Erosional exhumation is a common mechanism for sample cooling in fold-thrust belts. In our study area (Figure 2), a lack of extensional structures, insignificant Mesozoic rifting [e.g., Sempere et al., 2002], and volcanism spatially limited to the EC back-thrust belt supports that erosional exhumation was responsible for the cooling histories reported. Therefore, we assume that the initiation of deformation generates topography with erosion causing the onset of rapid $\left(>\sim 10^{\circ} \mathrm{C} / \mathrm{M} . \mathrm{y}\right)$ exhumation recorded by the thermochronometer data [after e.g., Coughlin et al., 1998; Sobel and Strecker, 2003; Barnes et al., 2006; Ege et al., 2007].

[36] Samples EC1-7 in the EC back-thrust belt are proximal $(\sim 4-25 \mathrm{~km})$ to Tertiary volcanism suggesting their cooling histories could be associated with magmatism rather than erosional exhumation (Figure 2a). For the following two reasons, we conclude that magmatic heating was insufficient to overprint the erosion-related cooling signal in the sample data. First, the AFT data display no correlation of age or track length distribution with respect to distance to the nearest volcanic outcrop (Figures 2a and 5 and Table 1). Second, we applied a step change in heating [after Ehlers, 2005] to compute the potential thermal disturbance caused by the Miocene to recent $(\sim<1-25 \mathrm{Ma})$ Los Frailes ignimbrite flows nearby [Riera-Kilibarda et al., 1994; Barke et al., 2007]. We assumed an initial intrusion temperature of $800^{\circ} \mathrm{C}$, a $50^{\circ} \mathrm{C}$ country rock temperature, a 300 -m-thick deposit (Riera-Kilibarda et al., 1994), and $32-64 \mathrm{~km}^{2} / \mathrm{Ma}$ thermal diffusivities based on average and measured values of conductivity, density, and heat capacity from southern EC rocks [Henry and Pollack, 1988; Ehlers, 2005]. The results predict a minor $\sim 10-13^{\circ} \mathrm{C}$ temperature change $4 \mathrm{~km}$ (our most proximal sample distance) from the intrusion center.

\subsection{Timing of Deformation at $\sim 19.5^{\circ} \mathrm{S}$}

[37] Previous work constraining the deformation history at $\sim 19.5^{\circ} \mathrm{S}$ suggests the EC fore-thrust belt deformation initiated in the middle to late Eocene $(\sim 35-40 \mathrm{Ma})$ followed by distributed deformation moving both west and east reaching the Altiplano and SA by the mid-Miocene ( $15 \mathrm{Ma}$ ) (Figures 9 and 10) [McQuarrie et al., 2005]. Late Eocene to earliest Oligocene (27-36 Ma) rapid erosion in the EC back-thrust and fore-thrust belts suggests distributed deformation at this time (Figures $9 \mathrm{~b}$ and $9 \mathrm{c}$ ). Two samples (EC1 and EC6) record the earliest cooling with robust grain/ track yields documenting erosion and deformation in the back-thrust belt 32-36 Ma (Figures $5 \mathrm{c}$ and 9c). Sample EC11 recorded the earliest cooling in the EC fore-thrust belt suggesting erosion and deformation started slightly later from 27 to $30 \mathrm{Ma}$ (Figures 6c and 9c). Two additional poor quality samples (EC9 and EC12) are consistent with this early Oligocene or even earlier erosion. Our chronology implies either (1) the EC back-thrust belt started deforming first or (2) the earliest ( 35-40 Ma) EC fore-thrust belt deformation was not recorded by our samples because they are limited to the younger, eastern portion as predicted by in-sequence deformation (Figures 2 and 9). Regardless, the results attest to near contemporaneous exhumation in both directions $\sim 27-36 \mathrm{Ma}$ (Figures $9 \mathrm{~b}$ and $9 \mathrm{c}$ ). Sediments shed by this exhumation were transported eastward into the adjacent foredeep deposits of the Incapampa syncline (Figures 2a, 9a, and 9b) [Horton, 2005; McQuarrie et al., 2005].

[38] Late Oligocene to early Miocene (19-25 Ma) cooling suggests deformation across structures in the $\mathrm{EC}$ as well as initial deformation of the IA at 19-22 Ma (Figure 9d). Although rapid erosion of samples EC8-10 is consistent with in-sequence deformation, they are all west of earlier exhumation recorded by EC11 indicating the opposite. Sample EC5 erosion is younger in age and intermediate in across-strike distance suggesting out-of-sequence deformation in the EC back-thrust belt. During this time (19$25 \mathrm{Ma}$ ), a change from foredeep to intermontane basin sedimentation suggests EC deformation waned while active deformation stepped eastward into the IA [Horton, 2005]. The extensive and contemporaneous rapid erosion portrays distributed deformation localizing sedimentation in the EC, which waned shortly thereafter, and eventually ceased by $\sim 15 \mathrm{Ma}$ [McQuarrie et al., 2005] or 21-25 Ma [Horton, 2005]. This history is supported by only minor resolved acceptable cooling in the EC back-thrust belt younger than $19 \mathrm{Ma}$.

[39] The 19-36 Ma deformation in the EC is associated with upper basement shortening (Figures 9a-9d) 
[McQuarrie, 2002; McQuarrie et al., 2005]. Similar magnitudes of shortening in the basement and cover rocks accounts for most of the present-day crustal thickness of the EC and presumably some of the elevation of the Andean plateau (Figure 9d) [McQuarrie, 2002]. This upper basement structure eventually feeds slip in the IA causing early deformation in the IA cover rocks (Figure 9d). The recorded uniform exhumation of the IA at 19-22 Ma can be explained in two ways: (1) by contemporaneous thrusting and exhumation in the IA cover rocks fed by upper basement deformation or (2) by more passive uplift above the leading edge of a subsequently lower basement structure as it began to migrate eastward feeding slip into the SA (Figures 9d and 9e). We prefer the latter explanation and suggest that the spatially uniform IA exhumation 19-22 Ma signifies the initiation age for lower basement shortening which begins after cessation of the upper structure [McQuarrie, 2002]. Since it is the older, upper basement structure that is responsible for a protoAndean plateau of modern width we infer this to been achieved by $\sim 15-20 \mathrm{Ma}$ (between Figures 9d and 9e) [McQuarrie, 2002; see also Barnes et al., 2006].

[40] Middle to late Miocene rapid cooling occurred in the EC back-thrust belt (11-16 Ma), easternmost IA (IA4; 3 $10 \mathrm{Ma}$ ), and initiated in the western SA (8-20 Ma) (Figure 9e). Cooling in the EC back-thrust belt may be the result of (1) strain accumulation from $\sim 12-20$ Ma evident by the locally deformed early to mid-Miocene Mondragon Formation 20-30 km northwest of Potosi [Kennan et al., 1995] or (2) simply enhanced protracted erosion after deformation had already ceased. No record of rapid exhumation and the existence of the undeformed, regional San Juan del Oro erosion surface [e.g., Gubbels et al., 1993] implies deformation in the EC fore-thrust belt ceased by $\sim 10 \mathrm{Ma}$. The late Miocene exhumation (from PAZ temperatures) of the eastern IA can be explained by continued migration of the lower basement structure as it advanced farther east [McQuarrie et al., 2005]. Limited thermogeochronology on Tertiary basin deposits and our recorded exhumation show deformation in the SA began $\sim 8-20$ Ma [Moretti et al., 1996; Jordan et al., 1997; Barke, 2004; Uba et al., 2006]. At about the same time, to the west, erosion and deformation of the Rio Mulato fold belt in the Altiplano is broadly constrained between 3 and $30 \mathrm{Ma}$. The unconformably overlying and folded Miocene Tambillo Formation sediments indicate both pre-Miocene and late Miocene ( 10-14 Ma) Altiplano deformation locally [Kennan et al., 1995; Lamb and Hoke, 1997].

[41] Late Miocene to Pliocene (2-8 Ma) rapid exhumation and deformation occurred throughout the central to eastern SA (Figure 9f). Local deposition of shallow marine rocks in the Yecua Formation [e.g., Hulka et al., 2006; Uba et al., 2006] place a maximum age of deformation on the SA structures sampled by SA3 -6 of $\sim 8$ Ma. Late Miocene exhumation is recorded by deposition of the Guandacay Formation (2.1-6 Ma) in the Chaco (Figure 1) to the east that indicates a proximal foredeep outboard this deformation [Uba et al., 2006]. Overlapping good modeling fits of samples SA3-4 from the west limb of the Sararenda anticline [McQuarrie, 2002] in the central SA record thrusting and exhumation starting 7-8 Ma. A dated tuff from fluvial terraces on the Caipipendi thrust hanging wall (second easternmost SA structure in Figure 8a) suggests inactivity for the last $1 \mathrm{Ma}$ [Barke, 2004; pg. 63]. The model-constrained cooling envelopes are consistent with in-sequence deformation propagating east with time as proposed [McQuarrie, 2002; McQuarrie et al., 2005]. However, others have suggested out-of-sequence deformation of the central and eastern SA structures over $\leq 6 \mathrm{Ma}$ [Moretti et al., 1996, Figure 11; Barke, 2004, pp. 148-151].

\subsection{Revised Shortening Rates}

[42] Previous shortening rates for the EC and IA were $\sim 9-11 \mathrm{~mm} / \mathrm{a}$ from $\sim 20-40$ Ma reducing to $\sim 4-5 \mathrm{~mm} / \mathrm{a}$ in the SA over the last 15-20 Ma (Table 3) [see also Ramos et al., 2004]. We revise these rates by assuming the EC started deforming $40 \mathrm{Ma}$ and the SA started either 8 or $20 \mathrm{Ma}$ as suggested by the minimum and maximum good fit exhumation histories of sample SA2 (Table 3). Two hundred eighteen kilometers of shortening across the EC and IA from 40 to $10-20 \mathrm{Ma}$ translates to a rate of $\sim 7-11 \mathrm{~mm} / \mathrm{a}$. Sixty-seven kilometers of shortening across the SA since 8 or 20 Ma produces shortening rates of $\sim 9$ or $\sim 4 \mathrm{~mm} / \mathrm{a}$, respectively. Our revised shortening rates presented here suggest Miocene to recent rates either decreased by half from a long-term average of $\sim 8 \mathrm{~mm} / \mathrm{a}$ or remained about the same to slightly increasing depending on the age of initial SA deformation and the end of EC deformation.

\subsection{Exhumation Estimates}

\subsubsection{Geothermal Gradients and Depth to Closure}

[43] The thermal structure across the thrust belt in southern Bolivia varies by a factor of two and has been well constrained by borehole measurements [Henry and Pollack, 1988; Hamza and Muñoz, 1996; Springer and Forster, 1998; Hamza et al., 2005]. We quantify exhumation magnitudes from AFT and ZFT effective closure depths using measured thermal gradients (Figure 10b) [Reiners and Brandon, 2006]. We assumed average closure temperatures of $110^{\circ} \mathrm{C}$ for AFT [e.g., Gallagher et al., 1998] and $240^{\circ} \mathrm{C}$ for ZFT [Brandon et al., 1998], and average surface temperatures of $10^{\circ} \mathrm{C}$ for the Altiplano and $\mathrm{EC}, 15^{\circ} \mathrm{C}$ for the IA, and $23^{\circ} \mathrm{C}$ for the SA [Springer and Forster, 1998; Instituto Geografico Militar, 2000]. Mean surface temperatures and proximal borehole measurements of the thermal gradient combine to represent the best available proxy for the thermal field through which the samples cooled. Our selection criteria for thermal gradient estimates include (1) measurement reliability, (2) location within the same physiographic province as the samples, (3) reported gradient has been corrected for near surface topographic perturbations, and (4) location of measurement is within one crustal thickness distance $(\sim 60-75 \mathrm{~km}$ in the Altipla$\mathrm{no} / \mathrm{EC}, \sim 50-60 \mathrm{~km}$ in the IA, and $\sim 40 \mathrm{~km}$ in the SA [Beck and Zandt, 2002]) of the samples to minimize regional variations in basal heat flux biasing our calculation.

[44] Five measurements in the Bolivian Altiplano estimate a mean thermal gradient of $38 \pm 10(1 \sigma)^{\circ} \mathrm{C} / \mathrm{km}[$ Henry 
Table 4. Exhumation Estimates for the Central Andean Fold-Thrust Belt $\left(\sim 19.5^{\circ} \mathrm{S}\right)$, Southern Bolivia ${ }^{\mathrm{a}}$

\begin{tabular}{|c|c|c|c|c|c|c|c|c|c|}
\hline & \multicolumn{3}{|c|}{ Cross Section } & \multirow[b]{2}{*}{$\begin{array}{l}\text { Thermochron } \\
\text { Estimate, km }\end{array}$} & \multirow[b]{2}{*}{$\begin{array}{l}\text { Cross Section } \\
\text { Estimate, }{ }^{\mathrm{b}} \mathrm{mm} / \mathrm{a}\end{array}$} & \multirow[b]{2}{*}{$\begin{array}{l}\text { Timescale } \\
\text { From }\end{array}$} & \multirow[b]{2}{*}{$\begin{array}{l}\text { Cross Section } \\
\text { Estimate, } \mathrm{mm} / \mathrm{a}\end{array}$} & \multirow[b]{2}{*}{$\begin{array}{c}\text { Thermochron Estimate, } \\
\mathrm{mm} / \mathrm{a}\end{array}$} & \multirow[b]{2}{*}{$\begin{array}{l}\text { Ege et al., }{ }^{\mathrm{c}} \\
\mathrm{mm} / \mathrm{a}\end{array}$} \\
\hline & $\begin{array}{l}\text { Estimate, } \\
\mathrm{km}^{2}\end{array}$ & $\begin{array}{l}\text { Length, } \\
\mathrm{km}\end{array}$ & $\begin{array}{l}\text { Estimate, } \\
\mathrm{km}\end{array}$ & & & & & & \\
\hline EC & $725-1285^{\mathrm{d}}$ & 194 & $3.7-6.6$ & $\begin{array}{l}2.6-6.5 \\
(<6-15 ; \mathrm{zft})\end{array}$ & - & $40 \mathrm{Ma}$ to 0 & $0.09-0.17$ & $\begin{array}{l}0.07-0.16 \\
(<0.15-0.38 ; \mathrm{zft})\end{array}$ & $0.1-0.3$ \\
\hline IA & $347-640^{\mathrm{d}}$ & 56 & $6.2-11.4$ & $\begin{array}{l}2.6-6.5 \\
(<6-15 ; \mathrm{zft})\end{array}$ & - & $20 \mathrm{Ma}$ to 0 & $0.31-0.57$ & $\begin{array}{c}0.13-.33 \\
(<0.30-0.75 ; \mathrm{zft})\end{array}$ & 0.4 \\
\hline SA & $192-432^{\mathrm{b}}$ & $130^{\mathrm{b}}$ & $1.5-3.3$ & $<3.8-7.0$ & $\begin{array}{l}0.08-0.17 \\
(20-0 \mathrm{Ma})\end{array}$ & $20 \mathrm{Ma}$ to 0 & $0.08-0.17$ & $<0.19-0.35$ & $0.9-1.6$ \\
\hline SA & $192-432^{b}$ & $130^{\mathrm{b}}$ & $1.5-3.3$ & $<3.8-7.0$ & $\begin{array}{l}0.10-0.22 \\
(15-0 \mathrm{Ma})\end{array}$ & $8 \mathrm{Ma}$ to 0 & $0.19-0.41$ & $<0.48-0.88$ & $0.9-1.6$ \\
\hline total & $1264-2357^{\mathrm{b}}$ & $380^{\mathrm{b}}$ & $3.33-6.20$ & $3.0-6.7^{\mathrm{e}}$ & $\begin{array}{l}0.08-0.16 \\
(40-0 \mathrm{Ma})\end{array}$ & $40 \mathrm{Ma}$ to 0 & $0.08-0.16$ & $0.08-0.17$ & \\
\hline
\end{tabular}

\footnotetext{
${ }^{\mathrm{a}}$ Thermochrology (thermochron) estimates from the AFT data unless noted otherwise; zft, zircon fission track.

${ }^{\mathrm{b}}$ From Barnes and Pelletier [2006].

${ }^{\mathrm{c}}$ Derived by AFT data from Ege et al. [2007, 2003] for $\sim 21.5^{\circ} \mathrm{S}$.

${ }^{\mathrm{d}}$ From McQuarrie et al. [2008].

eWeighted average exhumation relative to each zones length as percent of the total thrust belt length.
}

and Pollack, 1988]. The high gradient is attributed to the position of a shallow $(\sim 70 \mathrm{~km})$ asthenospheric mantle wedge, partial melts in the midcrust, and proximity to the volcanic arc to the west [Springer, 1999]. This high geothermal gradient suggests an erosion magnitude of $\sim 2.5 \mathrm{~km}$ (range $\sim 2-3.5 \mathrm{~km}$ ) for reset AFT samples. More specifically, the only measurement proximal to our Altiplano sample is located $\sim 50 \mathrm{~km}$ away at Nasama and has a gradient of $36^{\circ} \mathrm{C} / \mathrm{km} \pm 10 \%$ heat flow error [Henry and Pollack, 1988]. From this value, we estimate an exhumation magnitude of $\sim 2.8 \mathrm{~km}$ ranging from $\sim 2.5-3 \mathrm{~km}$ (Figure $10 \mathrm{~b})$. In comparison, previously estimated Oligocene paleogeothermal gradients in the Altiplano to the south range from 26 to $32^{\circ} \mathrm{C} / \mathrm{km} \pm \sim 20 \%$ [Ege et al., 2007] suggesting this exhumation magnitude estimate is a minimum.

[45] In the Bolivian Eastern Cordillera, twelve measurements constrain a mean thermal gradient of $26 \pm 8(1 \sigma)^{\circ} \mathrm{C} /$ $\mathrm{km}$ [Henry and Pollack, 1988]. The lower EC thermal gradient relative to the Altiplano is probably due to the large topographic effect from the higher relief (Figure 1). The $26 \pm 8(1 \sigma){ }^{\circ} \mathrm{C} / \mathrm{km}$ gradient suggests an erosion magnitude of $3.9 \mathrm{~km}$ (range 3 to $\sim 5.5 \mathrm{~km}$ ) for reset AFT samples and $9 \mathrm{~km}$ (range $7-13 \mathrm{~km}$ ) if any of the ZFT samples had been reset. More specifically, three most proximal measurements to our EC samples are located $\sim 100-150 \mathrm{~km}$ to the south and estimate a similar mean gradient of $27 \pm 11^{\circ} \mathrm{C} / \mathrm{km}$, but larger uncertainty (stations Choroloque, Tatasi, and Chilcobija from Henry and Pollack [1988]). This decreases the erosion magnitude estimate to $3.7 \mathrm{~km}$ and the range from 2.6 to $6.5 \mathrm{~km}$ for AFT and $\sim 8.5 \mathrm{~km}$ with a range of $6-15 \mathrm{~km}$ for ZFT (Figure 10b). Estimated EC Oligocene paleogeothermal gradients to the south are similar, ranging from 19 to $32^{\circ} \mathrm{C} / \mathrm{km} \pm \sim 20 \%$ [Ege et al., 2007].

[46] Unfortunately, no thermal gradient measurements exist for the IA. Therefore, we assume the gradient is the same as the $\mathrm{EC}$ at $27 \pm 11^{\circ} \mathrm{C} / \mathrm{km}$ with equivalent estimated erosion magnitudes (Figure 10b). The estimated IA Oligocene paleogeothermal gradient to the south is nearly identical at $26^{\circ} \mathrm{C} / \mathrm{km} \pm \sim 35 \%$ [Ege et al., 2007]. Regional heat flow studies treat the IA as part of the EC further justifying the assumption of similar gradients between the EC and IA [Springer and Forster, 1998; Springer, 1999].

[47] SA sample cooling ages are not reset by the Miocene to recent deformation allowing us to estimate a depth to AFT closure as a maximum limit on SA exhumation. Over 1500 measurements from the southern Bolivia SA and adjacent Chaco plain yield a mean geothermal gradient of $22.4^{\circ} \mathrm{C} / \mathrm{km} \pm \sim 35 \%$ (Figure 1) [Springer and Forster, 1998]. The low gradient is attributed to the SA being both the locus of substantial late Tertiary sedimentation and proximal to the cold, Brazilian shield to the east [Springer, 1999]. The $22.4^{\circ} \mathrm{C} / \mathrm{km} \pm \sim 35 \%$ gradient suggests the SA erosion magnitude is less than $\sim 4 \mathrm{~km}$ (range $\sim 3-6 \mathrm{~km}$ ). Locally, three measurements (stations Monteagudo, Camiri, and Guairay [Springer and Forster, 1998]) within $\sim 50 \mathrm{~km}$ of our samples suggest a lower mean gradient of $18 \pm$ $5^{\circ} \mathrm{C} / \mathrm{km}$ indicating an average maximum exhumation magnitude of $\sim 5 \mathrm{~km}$ with a range of $<3.8-7 \mathrm{~km}$ (Figure 10b).

[48] A systematic decrease in SA sample cooling age with depth allows us to semiquantitatively test the validity of using modern geothermal gradients to estimate erosion magnitude. We estimate the paleothermal gradient through which the SA samples were exhumed by assuming the reconstructed sample stratigraphic depths are correct, AFT closure is $110^{\circ} \mathrm{C}$, and the surface temperature is $23^{\circ} \mathrm{C}$ (Figure 8b). As we outline here, the AFT data imply the SA samples were exhumed from within a fossil AFT PAZ (Figure 8) [e.g., Fitzgerald et al., 1995]. First, mean track lengths are shortened, range from 9.97 to $11.64 \mu \mathrm{m}$, and their variance generally increases with original stratigraphic depth. Second, the percentage of reset individual grain ages within each sample (from $\sim 55-60 \%$ (SA3 and 6) to $100 \%$ (SA1)) increases with depth. Third, there is a systematic decrease in pooled age with depth; two shallow, late Paleozoic to early Mesozoic, concordant ages overlie two intermediate-depth samples of much younger, and more significantly reset Cretaceous age, which in turn overlie two mid-Eocene discordant ages (Figure 4). Fourth, sample cooling histories indicate residence in AFT PAZ temper- 
atures that increase with depth from $\sim 65-90^{\circ} \mathrm{C}$ (Figure $8 \mathrm{c}$; see also section 4.6). Finally, the youngest pooled ages (mid-Eocene) are discordant and substantially older than the maximum age of deformation in the SA ( 20 Ma [e.g., Barke, 2004; McQuarrie et al., 2005]), suggesting none of the samples were exhumed from above AFT closure by the Miocene deformation. On the basis of the sample depth profile, full closure must have occurred below the deepest sample at $\geq 6 \mathrm{~km}$ (gray zone in SA; Figures 4 and 8). This suggests the SA samples resided in a paleo-PAZ with a minimum depth of $6 \mathrm{~km}$ to the $110^{\circ} \mathrm{C}$ isotherm corresponding to a paleogradient of $<\sim 15^{\circ} \mathrm{C} / \mathrm{km}$. This is within the lower bound of the modern mean gradient $(18 \pm$ $5^{\circ} \mathrm{C} / \mathrm{km}$ ) used to estimate the exhumation magnitude above. 5.4.2. Exhumation Magnitude from the Balanced Section

[49] Balanced cross sections and their restorations provide an independent method for estimating the first-order spatial variations in erosion magnitude across the thrust belt [Barnes and Pelletier, 2006; McQuarrie et al., 2008]. In brief, the balancing of rock area can be used to reconstruct the amount of material eroded by projecting the stratigraphy and structures above the present-day topography in the balanced section (Figure 2). Although a simplification, dividing the estimated area removed by erosion by the modern length of the thrust belt provides an average, regional thickness of denudation. The eroded area estimates at $\sim 19.5^{\circ} \mathrm{S}$ in Table 4 both exclude (lower range) and include (upper range) a 3-km-thick Tertiary section (similar to the modern estimate [Horton and DeCelles, 1997]) based on preserved deposits throughout the EC that document the eastward migration of the foreland basin during the early to mid-Tertiary [DeCelles and Horton, 2003]. Estimates are $725-1285 \mathrm{~km}^{2}$ of material removed from the 194-km-wide $\mathrm{EC}, 347-640 \mathrm{~km}^{2}$ from the 56-km-wide IA, and 192-432 $\mathrm{km}^{2}$ from the $130-\mathrm{km}$-wide SA (Table 4). Total magnitude of removed material is estimated to be $1264-2357 \mathrm{~km}^{2}$.

\subsubsection{Synthesis of Exhumation Magnitudes and Rates} at $\sim 19.5^{\circ} \mathrm{S}$

[50] Table 4 shows a comparison between denudation estimates derived from both the thermochronology and the cross section. Both methods produce denudation estimates for the EC that range from $\sim 3-7 \mathrm{~km}$. Although exhumation is variable across the different EC structures, $\sim 4-7 \mathrm{~km}$ is most consistent among the various estimates (Table 4 and Figure 10b). Maximum exhumation of the EC is $<\sim 8.5 \mathrm{~km}$ constrained by several Paleozoic ZFT ages. The IA is unique in that the cross section estimate of erosion is greater than that given by the thermochronology $(\sim 3-6.5$ versus $\sim 6-11 \mathrm{~km}$ ) with the representative stratigraphy suggesting an intermediate value $\sim 5-7 \mathrm{~km}$. Significant structural overlap $(3-5 \mathrm{~km})$ recorded in the IA may have never been expressed as burial if erosion kept pace with faulting. Thus removal of material was lateral verses vertical making the integrated "vertical" amount of exhumation an overestimate. Exhumation estimates across the IA are most likely $\sim 4-6 \mathrm{~km}$. Maximum exhumation of the IA is also $<\sim 8.5 \mathrm{~km}$ as constrained by two Paleozoic ZFT ages. In the SA, the cross section, closure depth, and the stratigraphy combine to both estimate and limit the exhumation magnitude. The average SA thermal gradient estimate $(\sim 5 \mathrm{~km})$ is a maximum because it represents a depth to full AFT closure and none of the sample ages were fully reset by the Miocene to recent erosion and deformation. The stratigraphy estimates (4-6 km) probably represent maximums because (1) samplespecific reconstructed depths are up to $\sim 0.5 \mathrm{~km}$ less than these regionally averaged stratigraphic thicknesses and (2) the assumption of a 3-km-thick Tertiary fill might be too large. Give these considerations, we think the cross section-derived magnitude of $\sim 3 \mathrm{~km}(1.5-3.3 \mathrm{~km})$ is the best average estimate of the SA exhumation magnitude.

[51] We estimated exhumation rates from the cross section and thermochronology-derived magnitudes assuming simplistic timescales for the duration of exhumation across each zone (Table 4). Rates for the EC range from $\sim 0.1-0.2 \mathrm{~mm} / \mathrm{a}$ with a maximum of $\sim 0.4 \mathrm{~mm} / \mathrm{a}$ averaged over the last $40 \mathrm{Ma}$. IA rates are higher ranging from $\sim 0.1-0.6 \mathrm{~mm} / \mathrm{a}$ with a maximum of $\sim 0.8 \mathrm{~mm} / \mathrm{a}$ averaged over the last $20 \mathrm{Ma}$. Rates for the SA range from $\sim 0.1-0.2 \mathrm{~mm} / \mathrm{a}$ up to $\sim 0.4 \mathrm{~mm} / \mathrm{a}$ averaged over the last $20 \mathrm{Ma}$ or $\sim 0.2-0.4 \mathrm{~mm} / \mathrm{a}$ up to $\sim 0.9 \mathrm{~mm} / \mathrm{a}$ averaged over the last $8 \mathrm{Ma}$. However, rates on individual structures could be much higher, especially the eastern SA thrust sheets if they were exhumed as recently as the Pliocene (i.e., $\sim 5 \mathrm{Ma} ; 0.8-1.4 \mathrm{~mm} / \mathrm{a}$ ).

[52] In summary, exhumation magnitudes generally decrease both eastward and westward from local maximums of $\sim 6-8 \mathrm{~km}$ in the EC fore-thrust belt to $1.5-3.3 \mathrm{~km}$ in the $\mathrm{SA}$ and Altiplano (Figure 10b). Exhumation rates range from $\sim 0.1-0.2 \mathrm{~mm} / \mathrm{a}$ in the $\mathrm{EC}, \sim 0.1-0.6 \mathrm{~mm} / \mathrm{a}$ in the IA, and from $\sim 0.1-0.4$ to $1.4 \mathrm{~mm} / \mathrm{a}$ or more in the eastern SA.

\subsection{Along-Strike Variations in Southern Bolivia/ Northern Argentina $\left(19-23^{\circ} \mathrm{S}\right)$}

[53] The chronology of exhumation and deformation in the central Andean fold-thrust belt is generally similar, but differs in detail within an along-strike distance of $\sim 400 \mathrm{~km}$ from our study area southward to northernmost Argentina (Figures 1 and $10 \mathrm{a}$ ). At $\sim 21.5^{\circ} \mathrm{S}$, AFT exhumation began in the central EC during the late Eocene (36-40 Ma) followed by distributed EC deformation [Ege et al., 2007]. We document younger late Eocene to earliest Oligocene (27-36 Ma) distributed exhumation in the EC, to the east and west of the oldest cooling recorded at $\sim 21.5^{\circ} \mathrm{S}$ (Figure 10a), also suggesting distributed deformation. Wedgetop basin deposits near Tupiza $\left(\sim 21.5^{\circ} \mathrm{S}\right)$ suggest the EC back-thrust belt began $\sim 34 \mathrm{Ma}$ consistent with our earliest documented exhumation [Horton, 1998; Horton et al., 2002; McQuarrie et al., 2005]. Distributed exhumation existed across the entire $\mathrm{EC}$ at $21.5^{\circ} \mathrm{S}$ during the early Oligocene (27-33 Ma) [Ege et al., 2007], whereas we document distributed exhumation throughout the late Oligocene to earliest Miocene (19-30 Ma). In both transects $\left(19.5^{\circ}\right.$ and $21.5^{\circ} \mathrm{S}$ ), erosional cooling during these times is generally consistent with (1) mostly eastward propagation of deformation from the central EC and (2) out-of-sequence exhumation and deformation across the EC back-thrust belt that almost completely ceased by $\sim 20 \mathrm{Ma}$ [Ege et 
al., 2007]. A late pulse of late Miocene $(\sim 11-16 \mathrm{Ma})$ exhumation in the EC back-thrust belt at $\sim 19.5^{\circ} \mathrm{S}$ and 10-18 Ma growth structures in the western Tupiza basin at $\sim 21.5^{\circ} \mathrm{S}$ [Horton, 1998] suggest limited deformation continued in the EC until $\sim 10 \mathrm{Ma}$. Additionally, thermal histories from the Uyuni-Khenayani Fault zone in the central Altiplano $\left(21.5^{\circ} \mathrm{S}\right)$ show exhumation began $\sim 30 \mathrm{Ma}$ [Ege et al., 2007] consistent with our Altiplano sample in the Rio Mulato fold belt, the along-strike equivalent structure to the north.

[54] During the early Miocene (18-22 Ma), the IA became active as exhumation and deformation continued uniformly along strike from 19.5 to $21.5^{\circ} \mathrm{S}$ (Figure 10a) [Ege et al., 2007]. Middle to late Miocene ( 8-20 Ma) erosion and deformation continued into the eastern IA and western SA (Figure 10a) [Moretti et al., 1996; Echavarria et al., 2003; Ege et al., 2003; Uba et al., 2006]. Unfortunately, we can only say that model-constrained cooling of sample AL1 is consistent with initial cooling anytime between the early Oligocene and Pliocene (3-30 Ma). Several lines of evidence suggest deformation in the EC and Altiplano completely ceased by 7-13 Ma, including: minor folding of late Miocene $(\sim 10-14 \mathrm{Ma})$ sediments in the Rio Mulato fold belt in the Altiplano [Kennan et al., 1995; Lamb and Hoke, 1997], elimination of growth structure evidence near Tupiza $\left(21.5^{\circ} \mathrm{S}\right)$ [Horton, 1998], the undeformed San Juan del Oro erosion surface $\left(18-22+^{\circ} \mathrm{S}\right)$ [Gubbels et al., 1993], exhumation histories in the Uyuni-Khenayani Fault zone $\left(21.5^{\circ} \mathrm{S}\right)$ [Ege et al., 2007], and flat-lying ignimbrites. Finally, late Miocene to Pliocene (2-8 Ma) initial exhumation and deformation occurred in the central to eastern SA and continues today (Figure 10a) [see also Echavarria et al., 2003; Ege et al., 2003; Scheuber et al., 2006].

[55] Estimated magnitudes of exhumation across the thrust belt are remarkably similar between $\sim 19.5$ and $21.5^{\circ} \mathrm{S}$ (Figure 10b). A variety of methods have been used to estimate exhumation magnitudes across the southern Bolivia portion of the thrust belt: vitrinite reflectance and illite crystallinity (at $\sim 21.5^{\circ} \mathrm{S}$ ) [Kley and Reinhardt, 1994], representative stratigraphy (this study), mass deficits inferred from a balanced section (this study), and thermochronology $\left(\sim 19.5-21.5^{\circ} \mathrm{S}\right)$ [Ege et al., 2007; this study]. In summary, exhumation magnitudes generally range from $\sim 4-7 \mathrm{~km}$ in the EC (but may exceed that locally up to $<\sim 8.5 \mathrm{~km}$ ) with the vitrinite and illite data suggesting, in particular, the Ordovician rocks were buried to great depths $(\sim 5-7 \mathrm{~km}) \sim 350 \mathrm{Ma}$, and subsequently exhumed either (1) at a constant rate to the surface or (2) to $\sim 2-3 \mathrm{~km}$ depths by $\sim 300 \mathrm{Ma}$, followed by recent rapid exhumation to the surface in the Tertiary [Kley and Reinhardt, 1994]. In the IA, exhumation estimates range from $\sim 4-6 \mathrm{~km}$ (and $<\sim 8.5 \mathrm{~km}$ ) with the Devonian rocks supposedly first buried by $\sim 4-6 \mathrm{~km}$ of sediments that were later eroded by the end of the Carboniferous, and subsequently followed a similar thermal history to the SA to the present [Kley and Reinhardt, 1994]. Finally, estimates range from $\sim 2$ to $<5 \mathrm{~km}$ in the SA (Figure 10b and Table 4) [see also Kley and Reinhardt, 1994; Ege et al., 2007]. Estimated rates of exhumation in southern Bolivia range from $\sim 0.1$ to
$0.3 \mathrm{~mm} / \mathrm{a}$ in the $\mathrm{EC}$, from $\sim 0.1-0.6 \mathrm{~mm} / \mathrm{a}$ in the IA, and $\sim 0.1-1.6 \mathrm{~mm} / \mathrm{a}$ in the SA (Table 4) [Ege et al., 2007].

\subsection{Along-Strike Variations in Bolivia $\left(15-21.5^{\circ} \mathrm{S}\right)$}

[56] Comparison of exhumation and deformation in Bolivia $\left(15-21.5^{\circ} \mathrm{S}\right)$ suggests a relatively cohesive evolution with some distinctive differences. For this comparison we focus on "good fit" thermal histories reported in the literature. In general, the Bolivia EC experienced several phases of rapid exhumation since the Eocene. Initial deformation and exhumation began in the EC during the late Eocene to earliest Oligocene ( $\sim 30-40 \mathrm{Ma})$ [e.g., Gillis et al., 2006; Ege et al., 2007; and this study]. Next, the southern Altiplano and EC $\left(19.5-21.5^{\circ} \mathrm{S}\right)$ experienced extensive erosion and deformation throughout the Oligocene and into the earliest Miocene $(\sim 20-33 \mathrm{Ma})$ distinguished by out-of-sequence strain in the EC as demonstrated by this study and Ege et al. [2007]. Unfortunately, extreme exhumation of the northern EC fore-thrust belt has exposed the lowest Ordovician phyllites and slates [see cross section and sampling gap in Barnes et al., 2006; McQuarrie et al., 2008] which are poorly amenable to AFT analysis (e.g., sample EC4 in Barnes et al. [2006]) and hence to date, preclude any noteworthy local constraint on the Eocene-Oligocene exhumation history. Limited exhumation began in the northern IA by at least the late Oligocene $(>\sim 25 \mathrm{Ma})$, followed by substantial exhumation of the IA all along strike since the early to mid-Miocene ( 15-22 Ma) [see also Ege et al., 2007; McQuarrie et al., $2008]$.

[57] Latest Oligocene to earliest Miocene $(\sim 15-25 \mathrm{Ma})$ is a crucial time period in plateau development throughout Bolivia. Sediment provenance indicates eastern and western highlands suggestive of an internally drained proto-Altiplano by $\sim 25 \mathrm{Ma}$ [Horton et al., 2002]. Transition from foredeep to intermontane sedimentation $\sim 21-25 \mathrm{Ma}$ is immediately followed by a severe reduction (but not complete cessation) of upper crustal deformation throughout the EC [Horton, 2005]. And finally, kinematic reconstructions suggest IA exhumation (and potentially the onset of SA exhumation as well) both across and along strike $\sim 15-$ $20 \mathrm{Ma}$ is associated with the onset of lower basement deformation signifying the modern width of the plateau was established by this time [McQuarrie, 2002; Barnes et al., 2006; and this study].

[58] The northern EC experienced a second exhumation phase during the middle to late Miocene $(\sim 11-15 \mathrm{Ma})$ to present [Benjamin et al., 1987; Barnes et al., 2006; Gillis et al., 2006; Safran et al., 2006; McQuarrie et al., 2008]. This young $(<\sim 28 \mathrm{Ma})$ exhumation is unrelated to deformation as constrained by the maximum age of growth structures in the local synorogenic sediments of the Luribay and Salla formations [McFadden et al., 1985; Sempere et al., 1990; Lamb and Hoke, 1997; Kay et al., 1998; Gillis et al., 2006; McQuarrie et al., 2008]. SA exhumation began in the west $\sim 8-20$ Ma all along strike [Moretti et al., 1996; Ege et al., 2003; Barnes et al., 2006; Scheuber et al., 2006], perhaps contemporaneous with a third exhumation pulse $(11-16 \mathrm{Ma})$ 
in the southern EC back-thrust belt $\left(19.5^{\circ} \mathrm{S}\right)$ related to deformation or postdeformation erosion. The northern Altiplano experienced late Miocene exhumation and deformation between $\sim 5-11$ Ma constrained by mapping, thermochronology, sedimentology of neotectonic strata, and geochronology of volcanic rocks [Lamb and Hoke, 1997; Barnes et al., 2006; McQuarrie et al., 2008]. In contrast, the last gasps of shortening in the southern Altiplano and EC ceased by $\sim 7-13 \mathrm{Ma}$ [Gubbels et al., 1993; Kennan et al., 1995; Lamb and Hoke, 1997; Horton, 1998; Müller et al., 2002; Ege et al., 2007]. Finally, exhumation is consistent with an eastward migration through the central and eastern SA during the Mio-Pliocene $(\sim 2-8 \mathrm{Ma})$ in the south $\left(19.5-21.5^{\circ} \mathrm{S}\right)$ [Ege et al., 2003; Scheuber et al., 2006], but maybe more spatially uniform and somewhat earlier ( $\sim 5-12 \mathrm{Ma}$ at $1 \sigma$ uncertainty; $\sim 4-$ $19 \mathrm{Ma}$ at 2 $\sigma$ ) in the north [Barnes et al., 2006]. However, detailed analyses of structural geometries and isolated geochronology suggest some out-of-sequence deformation in the SA [Baby et al., 1995; Roeder and Chamberlain, 1995; Moretti et al., 1996; Barke, 2004].

[59] Comparison of exhumation magnitudes along strike $\left(15-21.5^{\circ} \mathrm{S}\right)$ suggests most significant variations in the EC with only minor differences in the Altiplano, IA, and SA. Exhumation magnitudes for the Altiplano range from $\sim 2-$ $4 \mathrm{~km}$ [see also Barnes et al., 2006]. Reset biotite and muscovite ${ }^{40} \mathrm{Ar} /{ }^{39} \mathrm{Ar}$ and ZFT ages in the northern EC fore-thrust belt suggest $\sim 9-11 \mathrm{~km}$ of Tertiary erosion [e.g., Gillis et al., 2006] whereas local maximums from the southern portion range from $\sim 6-8 \mathrm{~km}$ (Figure 10b) [see also Ege et al., 2007]. However, neither ${ }^{40} \mathrm{Ar} /{ }^{39} \mathrm{Ar}$ nor ZFT ages have been measured in the southern EC fore-thrust belt. Estimates for the EC back-thrust belt are $\sim 3-6 \mathrm{~km}$ with unreset ZFT ages limiting the maximum to $<\sim 8.5 \mathrm{~km}$ (Figure 10b) [McQuarrie et al., 2008]. The best estimates for the IA are $\sim 5-9 \mathrm{~km}$ in the north and from $\sim 4-6 \mathrm{~km}$ in the south IA with Paleozoic ZFT ages limiting the maximum to $<\sim 8 \mathrm{~km}$ in the south [see also McQuarrie et al., 2008]. Finally, estimates for the SA in the north are $\sim 3-4 \mathrm{~km}$ (from reset young component AFT ages) with an upper limit of $<\sim 7 \mathrm{~km}$ from unreset zircon (U-Th)/He ages [Barnes et al., 2006]. The best southern SA estimates are $\sim 3 \mathrm{~km}$ by AFT samples exhumed from PAZ temperatures.

[60] Estimated rates of deformation in Bolivia (15$19.5^{\circ} \mathrm{S}$ ) are similar. The EC and IA regions shortened at rates of $\sim 7-11 \mathrm{~mm} / \mathrm{a}$ from $\sim 25-40 \mathrm{Ma}$ (Figures 9 and 10) [see also McQuarrie et al., 2008]. The SA shortened at rates of $\sim 4$ or $8 \mathrm{~mm} / \mathrm{a}$ depending on initiation of deformation either $\sim 15-20 \mathrm{Ma}$ or $\sim 8 \mathrm{Ma}$ [McQuarrie et al., 2008]. Average shortening rates at $21.5^{\circ} \mathrm{S}$ are $0-8 \mathrm{~mm} / \mathrm{a}$ since $30-$ $46 \mathrm{Ma}, 5-10 \mathrm{~mm} / \mathrm{a}$ since $10-30 \mathrm{Ma}$, and 6-14 mm/a since $10 \mathrm{Ma}$ [Elger et al., 2005; Oncken et al., 2006].

\subsection{Implications for Plateau Growth Models}

[61] The integrated exhumation and deformation record discussed above provides important constraints on central Andean plateau growth and allows associated insights into proposed models of plateau evolution. First, lithospheric weakening is commonly considered a precondition of the early Eocene through Oligocene distributed deformation in the plateau region because of shortening and magmatism [e.g., Isacks, 1988; Francis and Hawkesworth, 1994; Wdowinski and Bock, 1994]. However, deformation generally precedes magmatism [e.g., Elger et al., 2005; Ege et al., 2007; and this study] and the regional time-space distribution of deformation and magmatism precludes a direct connection between the two because they vary independently [Trumbull et al., 2006]. Second, the proposal that mantle delamination caused $2-3+\mathrm{km}$ of rapid Andean plateau surface uplift $\sim 6-10 \mathrm{Ma}$ also implies concomitant eastward propagation of accelerated deformation into the SA [Garzione et al., 2006; Ghosh et al., 2006]. The SA exhumation and deformation history is certainly consistent with activation $\sim 8 \mathrm{Ma}$ [Echavarria et al., 2003; Ege et al., 2003; Barnes et al., 2006; Scheuber et al., 2006; and this study]. However, several western SA thermochronometer samples are also consistent with earlier initial cooling $\sim 10-20 \mathrm{Ma}$ [Barnes et al., 2006; and this study] implying a more gradual eastward migration of deformation from the IA starting $\sim 20 \mathrm{Ma}$ which may not be consistent with the delamination model.

[62] We interpret the central Andean fold-thrust belt to be deforming as a Coulomb wedge which seeks to maintain taper by both eastward propagation and out-of-sequence deformation [Dahlen and Suppe, 1988; Dahlen, 1990; Willett, 1992]. The early Eocene-Oligocene distributed plateau region deformation could represent episodes of alternating wedge conditions leading to both propagation and significant internal deformation, whereas the eastward propagation since $\sim 20$ Ma could represent a more stable condition promoting advance at a potentially reduced rate (Table 4). Evidence of out-of-sequence SA deformation $\leq 6$ Ma [Moretti et al., 1996; Barke, 2004] suggests some relatively recent readjustments of the wedge to rebuilt taper. The history and changing modes of deformation of a central Andes ancient analog, the Nevadaplano and Sevier foldthrust belt in the western United States [e.g., DeCelles, 2004], has been previously interpreted this way [DeCelles and Mitra, 1995]. The latitudinal contrast in erosion, which is believed to have existed since potentially as early as the late Miocene [Horton, 1999; Barnes and Pelletier, 2006], is probably effecting the wedge as suggested by (1) a larger magnitude of concentrated exhumation in the northern EC ( $\sim 9-11 \mathrm{~km})$ compared to more distributed and limited exhumation in the south $(<\sim 8.5 \mathrm{~km})$ constrained by ZFT and ${ }^{40} \mathrm{Ar} /{ }^{39} \mathrm{Ar}$ thermochronometers [Benjamin et al., 1987; Gillis et al., 2006; this study] and (2) younger and mixed reset AFT cooling ages in the northern SA [Barnes et al., 2006] compared to the unreset and discordant Mesozoic AFT cooling ages in the southern SA [Scheuber et al., 2006; this study].

\section{Summary and Conclusions}

[63] This study presents 23 new apatite and zircon fission track (AFT and ZFT) analyses spanning the entire central 
Andean fold-thrust belt at its widest extent in Bolivia at $\sim 19.5^{\circ} \mathrm{S}$. Exhumation histories were quantified with thermal modeling, interpreted in the context of the regional geology, stratigraphy, geothermal gradients, and mass deficits inferred from a balanced section, and then integrated with previous kinematic reconstructions and associated foreland basin deposits to refine the chronology and rate of deformation. Primary conclusions of this study are:

[64] 1. Cooling histories inverted from the AFT data are consistent with Eocene to recent rapid cooling. (1) Distributed exhumation of the Eastern Cordillera (EC) occurred in the late Eocene to earliest Oligocene (27-36 Ma) and continued during the late Oligocene to early Miocene (19-25 Ma), (2) exhumation of the eastern Altiplano began anytime from 3 to $30 \mathrm{Ma}$, (3) exhumation across most of the Interandean zone (IA) began 19-22 Ma, (4) exhumation of the western Subandes (SA) began 8-20 Ma, perhaps contemporaneous with a third exhumation pulse (11$16 \mathrm{Ma}$ ) in the EC back-thrust belt, and (5) exhumation of the central-to-western SA propagated eastward during the late Miocene-Pliocene (2-8 Ma).

[65] 2. The exhumation chronologies characterize EC deformation as distributed, as opposed to previous kinematic reconstructions that assumed in-sequence deformation in the direction of transport. However, Miocene to recent $(\sim 0-20 \mathrm{Ma})$ exhumation of the IA and SA is consistent with in-sequence deformation progressing eastward toward the Chaco foreland. We propose that the propagation of deformation from the EC toward the SA, marked by uniform IA exhumation 19-22 Ma, indicates a switch from a higher to lower basement structure. The cessation of most EC exhumation signifies establishment of the modern Andean plateau width and substantial crustal thickness briefly thereafter by $\sim 15-20$ Ma.

[66] 3. Exhumation magnitudes decrease laterally from local maximums of $<8 \mathrm{~km}$ in the $\mathrm{EC}$ fore-thrust belt to average values of $\sim 4-7 \mathrm{~km}, \sim 2.5-3 \mathrm{~km}$ in the Altiplano, $\sim 4-6 \mathrm{~km}$ in the IA, and $\sim 3 \mathrm{~km}$ in the SA. Paleozoic ZFT ages constrain maximum exhumation of the EC back-thrust belt and IA to $<\sim 8.5 \mathrm{~km}$.

[67] 4. Shortening rates across the EC and IA from 40 to $10-20 \mathrm{Ma}$ range from $\sim 7$ to $11 \mathrm{~mm} / \mathrm{a}$. Shortening rates across the SA since 8 or $20 \mathrm{Ma}$ range from $\sim 9$ to $\sim 4 \mathrm{~mm} / \mathrm{a}$. These rates suggest the Miocene to recent rates either decreased by half from the long-term average of $\sim 8 \mathrm{~mm} / \mathrm{a}$ or remained about the same or slightly increased depending on the age of initial SA deformation and the end of EC deformation.

[68] Finally, we draw three important generalizations from the integrated record of central Andean fold-thrust belt exhumation, deformation, and sedimentation throughout Bolivia; (A) Deformation began in the EC $\sim 35-40 \mathrm{Ma}$ and continued in a distributed manner throughout the Altiplano and EC regions until $\sim 20-25$ Ma with minor, isolated deformation continuing until $\sim 10 \mathrm{Ma}$. (B) Uniform exhumation in the southern IA $\sim 18-22$ Ma signifies establishment of the modern width of the Andean plateau with unknown, but significant crustal thickness shortly thereafter by $\sim 15-20 \mathrm{Ma}$. (C) From $\sim 20 \mathrm{Ma}$ to present, deformation mostly propagated eastward from the IA with evidence for minor out-of-sequence deformation in the central-to-eastern SA.

\section{Appendix A: Representative Stratigraphy}

[69] Representative stratigraphic sections were constructed from measurements of the balanced and restored section of McQuarrie [2002] (Figures 2 and 4). We describe the methodology proceeding from west to east and upsection from the Ordovician through the Tertiary. Stratigraphic thicknesses and sample location errors are estimated to be $\pm \sim 20 \%$ arbitrarily, but are not included for brevity.

[70] We estimate the average thickness of the Ordovician at $5.5 \mathrm{~km}$ in the EC. The Silurian thins eastward from 4.2 to $1.2 \mathrm{~km}$ with averages of $2725 \mathrm{~m}$ and $1500 \mathrm{~m}$ for the backthrust and fore-thrust zones, respectively. The Devonian is absent in most of the EC except for the eastern margin where it thickens rapidly to a maximum of $1650 \mathrm{~m}$ at the EC-IA boundary for an average of $825 \mathrm{~m}$ in the EC forethrust belt. Presumably, the EC Devonian rocks were eroded in pre-Mesozoic time [McQuarrie and DeCelles, 2001]. The Carboniferous section is missing, the Mesozoic rocks are $\sim 1500 \mathrm{~m}$ thick, and Tertiary rocks are only present locally [e.g., Horton, 2005].

[71] The Ordovician thins eastward $(4.15-1.65 \mathrm{~km})$ with an average thickness of $2.9 \mathrm{~km}$ in the IA. The Silurian thins eastward from 2.5 to $1.25 \mathrm{~km}$ for an average of $1875 \mathrm{~m}$. The average Devonian thickness is $2.5 \mathrm{~km}$ because it thickens eastward from 1.65 to $3.35 \mathrm{~km}$. The Carboniferous is absent here. The Mesozoic rocks range from $850 \mathrm{~m}$ thick to absent from east to west for an average of $425 \mathrm{~m}$. Tertiary rocks are not present regionally.

[72] Minimal Devonian is exposed in the SA, but it supposedly thins from 3950 to $500 \mathrm{~m}$ for an average of $2225 \mathrm{~m}$. The average Carboniferous thickness is 1700 because it ranges from 1150 to $2250 \mathrm{~m}$. Mesozoic units range from 520 to $1200 \mathrm{~m}$ thick for an average of $860 \mathrm{~m}$. Finally, Tertiary sediment thicknesses vary greatly among the constraints, but average $3 \mathrm{~km}$ with a range from 2 to $4 \mathrm{~km}$.

[73] Studies tracked the early mid-Tertiary migration of the central Andean foreland basin system as a proxy of the hinterland thrust belt evolution [DeCelles and Horton, 2003; Horton, 2005; McQuarrie et al., 2005]. This suggests that Tertiary foreland deposits existed outboard the thrust belt to the east which was subsequently uplifted and mostly eroded from the EC and IA. Consequently, we assume a uniform 3-km-thick Tertiary foreland section from the EC through the SA in our representative sections [after Barnes and Pelletier, 2006].

\section{Appendix B: Analytical Procedures}

[74] Mineral separations and fission track analyses were performed using standard techniques by Apatite to Zircon, Inc. Apatite and zircon concentrates were created using standard heavy-liquid techniques [see Donelick et al., 2005, Appendix 1]. Apatite grains were immersed in an epoxy resin that was cured at $90^{\circ} \mathrm{C}$ for $1 \mathrm{~h}$. The cured mounts were 
polished to expose grain surfaces, followed by etching in $5.5 \mathrm{~N} \mathrm{HNO}_{3}$ for $20.0 \mathrm{~s}( \pm 0.5 \mathrm{~s})$ at $21^{\circ} \mathrm{C}\left( \pm 1^{\circ} \mathrm{C}\right)$ to reveal all natural fission tracks. Zircon grains were mounted in FEP Teflon. The zircon mounts were also polished followed by immersion in a eutectic melt of $\mathrm{NaOH}+\mathrm{KOH}$ at $\sim 210^{\circ} \mathrm{C}$ $\left( \pm 10^{\circ} \mathrm{C}\right)$ for $\sim 37 \mathrm{~h}$ and $10 \mathrm{~min}$ to adequately reveal the naturally occurring tracks.

[75] Most AFT analyses and all ZFT analyses presented here used the laser ablation (LA-ICPMS) method of Donelick et al. [2005]. Age standards used to calculate the LA-ICPMS zeta calibration factor were (1) Durango apatite $(30.6 \pm 0.3 \mathrm{Ma})$ from Cerro de Mercado, Mexico, and (2) Fish Canyon zircon $(27.9 \pm 0.7 \mathrm{Ma})$ from the San Juan Mountains, Colorado. AFT sample 713-5B and 7141B analyses used the external detector method [e.g., Gallagher et al., 1998]. The age standard used to calculate the traditional zeta factor was the same Durango apatite. A zeta calibration factor of $113.8 \pm 2.9(1 \sigma)$ (for RAD) was used.

[76] Following age analysis, grain mounts were irradiated by a ${ }^{252} \mathrm{Cf}$ source in a vacuum to enhance the measurability of the natural tracks [Donelick and Miller, 1991]. The irradiated grain mounts were reimmersed in $5.5 \mathrm{~N} \mathrm{HNO}_{3}$ for $20.0 \mathrm{~s}( \pm 0.5 \mathrm{~s})$ at $21^{\circ} \mathrm{C}\left( \pm 1^{\circ} \mathrm{C}\right)$ to reveal any horizontal, confined tracks. Both the track lengths and their angle relative to the crystallographic c axis were recorded. For each apatite grain age and track length, a mean Dpar value was determined from 1 to 4 measurements.

\section{Appendix C: AFT Data Analysis and Thermal Modeling}

[77] We used BinomFit to deconvolve the component ages for sample $714-1 \mathrm{~B}$ because it is both discordant and was analyzed with the external detector method. The new LA-ICPMS-derived data are not compatible with BinomFit because a non-Poissonian counting process is used in the measurement of the $\mathrm{U}, \mathrm{Ca}$, and $\mathrm{Si}$ isotopes, and thus the same statistical techniques cannot be applied. Consequently, we conservatively modeled all the remaining sample AFT data as one kinetic population.

[78] We conducted inverse thermal modeling of the AFT data with HeFTy beta version 6 [Ehlers et al., 2005;
Ketcham, 2005] with the Cf irradiation option activated. We used $2 \sigma$ uncertainty, included Dpar values, and both the traditional zeta and LA-ICPMS ratio methods as appropriate with the age and length data.

[79] For each sample, an initial, open-ended model was performed with all sample data as one kinetic population with a starting temperature of (1) $200^{\circ} \mathrm{C}$ at a time that is 50 Ma older than deposition and (2) $20^{\circ} \mathrm{C}$ at present. This model was run to assess how distinct the recent cooling history is without bias from multiple user-defined constraints. Next, a more refined model was run by imposing additional geologic constraints such as a fixed $10-30^{\circ} \mathrm{C}$ temperature equal to the deposition age and a fixed 50$180^{\circ} \mathrm{C}$ temperature equal in age to either (1) the $2 \sigma$ range in the concordant pooled age or the $2 \sigma$ range in discordant component age(s) (if available) or (2) between the sample depositional age and $1 \mathrm{Ma}$ for discordant samples to allow for the maximum flexibility in attempted thermal history paths explored. These models defined the envelope of permissible thermal histories given the samples' local geologic context. Since we cannot delineate component ages and kinetic populations for discordant samples, we followed this conservative approach and report the refined model results. This approach allows for identification of the full range of sample cooling histories permitted by all measured ages and track lengths.

[80] Modeled thermal history segments were designated as episodic style, monotonic, and random spacing with halved 5 times $(5 \mathrm{E})$ to provide the most simple. yet flexible ("allowed complexity") style of cooling paths between constraints [Ketcham, 2005]. A $40^{\circ} \mathrm{C} / \mathrm{Ma}$ maximum cooling/heating rate was imposed on all segments. Inversions were run with a Monte Carlo search and 50,000 attempted paths.

[81] Acknowledgments. We thank SERGEOTECMIN of La Paz, Bolivia, and especially Jaime Tito for logistical support. Nadja Insel assisted in the field. Financial support was provided to T. Ehlers by NSF grant EAR 0409289 and by a University of Michigan Scott Turner Award in the Earth Sciences to J. Barnes. Discussions with B. Horton were also helpful. Reviews by J. Spotila, V. Ramos, and Associate Editor M. Rushmore greatly improved the manuscript.

\section{References}

Allmendinger, R. W., and T. L. Gubbels (1996), Pure and simple shear plateau uplift, Altiplano-Puna, Argentina and Bolivia, Tectonophysics, 259, 1-13, doi:10.1016/0040-1951(96)00024-8.

Allmendinger, R. W., T. E. Jordan, S. M. Kay, and B. L. Isacks (1997), The evolution of the Altiplano-Puna Plateau of the central Andes, Annu. Rev. Earth Planet. Sci., 25, 139-174, doi:10.1146/annurev.earth.25.1.139.

Baby, P., R. Limachi, I. Moretti, E. Mendez, J. Oller, B. Guiller, and M. Specht (1995), Petroleum system of the northern and central Bolivian sub-Andean zone, AAPG Mem., 62, 445 - 458 .

Barke, R. (2004), Late Cenozoic tectonic and topographic evolution of the Bolivian Andes, Ph.D. thesis, 380 pp, Univ. of Oxford, Oxford, UK.

Barke, R., and S. Lamb (2006), Late Cenozoic uplift of the Eastern Cordillera, Bolivian Andes, Earth Planet. Sci. Lett., 249, 350-367, doi:10.1016/ j.eps1.2006.07.012.
Barke, R., S. Lamb, and C. MacNiocaill (2007), Late Cenozoic bending of the Bolivian Andes: New paleomagnetic and kinematic constraints, J. Geophys. Res., 112, B01101, doi:10.1029/2006JB004372.

Barnes, J. B., and J. D. Pelletier (2006), Latitudinal variation of denudation in the evolution of the Bolivian Andes, Am. J. Sci., 306, 1-31, doi:10.2475 ajs.306.1.1.

Barnes, J. B., T. A. Ehlers, N. McQuarrie, and J. D. Pelletier (2006), Variations in Eocene to recent erosion across the central Andean fold-thrust belt, northern Bolivia: Implications for plateau evolution, Earth Planet. Sci. Lett., 248, 118-133, doi:10.1016/j.epsl.2006.05.018.

Beaumont, C., R. A. Jamieson, M. H. Nguyen, and B. Lee (2001), Himalayan tectonics explained by extrusion of a low-viscosity crustal channel coupled to focused surface denudation, Nature, 414, 738-742, doi:10.1038/414738a.
Beck, S. L., and G. Zandt (2002), The nature of orogenic crust in the central Andes, J. Geophys. Res., 107(B10), 2230, doi:10.1029/2000JB000124.

Benjamin, M. T., N. M. Johnson, and C. W. Naeser (1987) Recent rapid uplift in the Bolivian Andes; evidence from fission-track dating, Geology, 15, 680-683, doi:10.1130/0091-7613(1987)15<680:RRUITB> 2.0.CO;2.

Brandon, M. T. (1992), Decomposition of fission-track grain-age distributions, Am. J. Sci., 292, 535-564.

Brandon, M. T. (2002), Decomposition of mixed grain age distributions using BinomFit, Track, 24, $13-18$.

Brandon, M., M. Roden-Tice, and J. Garver (1998), Late Cenozoic exhumation of the Cascadia accretionary wedge in the Olympic Mountains, northwest Washington State, Geol. Soc. Am. Bull., 110, 985-1009, doi:10.1130/0016-7606(1998)110<0985: LCEOTC $>2.3 . \mathrm{CO} ; 2$. 
Burtner, R. L., A. Nigrini, and R. A. Donelick (1994), Thermochronology of Lower Cretaceous source rocks in the Idaho-Wyoming thrust belt, $A A P G$ Bull., 78, 1613-1636.

Carlson, W. D., R. A. Donelick, and R. A. Ketcham (1999), Variability of apatite fission-track annealing kinetics; I. Experimental results, Am. Mineral., 84, $1213-1223$.

Coudert, L., M. Frappa, C. Viguier, and R. Arias (1995), Tectonic subsidence and crustal flexure in the Neogene Chaco Basin of Bolivia, Tectonophysics, 243, 277-292, doi:10.1016/0040-1951(94) 00123-Q.

Coughlin, T. J., P. B. O’Sullivan, B. P. Kohn, and R. J. Holcombe (1998), Apatite fission-track thermochronology of the Sierras Pampeanas, central western Argentina; implications for the mechanism of plateau uplift in the Andes, Geology, 26, 999-1002, doi:10.1130/0091-7613(1998) 026<0999:AFTTOT $>2.3 . \mathrm{CO} ; 2$

Dahlen, F. A. (1990), Critical taper model of fold-andthrust belts and accretionary wedges, Annu. Rev. Earth Planet. Sci., 18, 55-99, doi:10.1146/annurev.ea.18.050190.000415.

Dahlen, F. A., and J. Suppe (1988), Mechanics, growth, and erosion of mountain belts, in Processes in Continental Lithospheric Deformation, edited by S. P. Clark Jr., B. C. Burchfiel, and J. Suppe, Spec. Pap. Geol. Soc. Am., 218, 161-178.

DeCelles, P. G. (2004), Late Jurassic to Eocene evolution of the Cordilleran thrust belt and foreland basin system, western U.S, Am. J. Sci., 304, 105-168, doi:10.2475/ajs.304.2.105

DeCelles, P. G., and B. K. Horton (2003), Early to middle Tertiary foreland basin development and the history of Andean crustal shortening in Bolivia, Geol. Soc. Am. Bull., 115, 58-77, doi:10.1130/ 0016-7606(2003)115<0058:ETMTFB >2.0.CO;2.

DeCelles, P. G., and G. Mitra (1995), History of the Sevier orogenic wedge in terms of critical taper models, northeast Utah and southwest Wyoming, Geol. Soc. Am. Bull., 107, 454-462, doi:10.1130/ 0016-7606(1995)107<0454:HOTSOW >2.3.CO;2.

Dodson, M. H. (1973), Closure temperature in cooling geochronological and petrological systems, Contrib. Mineral. Petrol., 40, 259-274, doi:10.1007/ BF00373790

Donelick, R. A., and D. S. Miller (1991), Enhanced TINT fission track densities in low spontaneous track density apatites using ${ }^{252} \mathrm{Cf}$-derived fission fragment tracks: A model and experimental observations, Nucl. Tracks Radiat. Meas., 18, 301-307, doi:10.1016/1359-0189(91)90022-A

Donelick, R. A., P. B. O'Sullivan, and R. A. Ketcham (2005), Apatite fission-track analysis, in Low-Temperature Thermochronology: Techniques, Interpretations, and Applications, Rev. Mineral. Geochem. vol. 58, edited by P. W. Reiners and T. A. Ehlers, pp. 49-94, Mineral. Soc. of Am., Chantilly, Va.

Dunn, J., K. Hartshorn, and P. Hartshorn (1995), Structural styles and hydrocarbon potential of the subAndean thrust belt of southern Bolivia, AAPG Mem., 62, 523-543.

Echavarria, L., R. Hernandez, R. Allmendinger, and J. Reynolds (2003), Subandean thrust and fold belt of northwestern Argentina: Geometry and timing of the Andean evolution, AAPG Bull., 87, 965-985.

Ege, H., E. R. Sobel, V. Jacobshagen, E. Scheuber, and D. Mertmann (2003), Exhumation history of the central Andes of southern Bolivia by apatite fission track dating, Rev. Tec. Yacimientos Petrol. Fis. Bolivianos, 21, 165-172.

Ege, H., E. R. Sobel, E. Scheuber, and V. Jacobshagen (2007), Exhumation history of the southern Altiplano plateau (southern Bolivia) constrained by apatite fission-track thermochronology, Tectonics, 26, TC1004, doi:10.1029/2005TC001869.

Ehlers, T. A. (2005), Crustal thermal processes and the interpretation of thermochronometer data, in LowTemperature Thermochronology: Techniques, Interpretations, and Applications, Rev. Mineral. Geochem., vol. 58, edited by P. W. Reiners and
T. A. Ehlers, pp. 315-350, Mineral. Soc. of Am. Chantilly, Va.

Ehlers, T. A., et al. (2005), Computational tools for low-temperature thermochronometer Interpretation, in Low-Temperature Thermochronology: Techniques, Interpretations, and Applications, Rev. Miner al. Geochem., vol. 58, edited by P. W. Reiners and T. A. Ehlers, pp. 589-622, Mineral. Soc. of Am. Chantilly, Va.

Elger, K., O. Oncken, and J. Glodny (2005), Plateaustyle accumulation of deformation: Southern Altiplano, Tectonics, 24, TC4020, doi:10.1029/ 2004TC001675.

Fitzgerald, P. G., R. B. Sorkhabi, T. F. Redfield, and E. Stump (1995), Uplift and denudation of the centra Alaska Range: A case study in the use of apatite fission track thermochronology to determine absolute uplift parameters, J. Geophys. Res., 100, $20,175-20,191$

Francis, P. W., and C. J. Hawkesworth (1994), Late Cenozoic rates of magmatic activity in the Centra Andes and their relationships to continental crust formation and thickening, J Geol. Soc. London, 151, 845-854, doi:10.1144/gsjgs.151.5.0845.

Gagnier, P. Y., A. Blieck, C. C. Emig, T. Sempere, D. Vachard, and M. Vanguestaine (1996), New paleontological and geological data on the Ordovician and Silurian of Bolivia, J.S. Am. Earth Sci., 9, 329 347, doi:10.1016/S0895-9811(96)00018-1.

Galbraith, R. F. (1981), On statistical models for fission track counts, J. Int. Assoc. Math. Geol., 13, $471-$ 478, doi:10.1007/BF01034498

Gallagher, K., R. Brown, and C. Johnson (1998), Fission track analysis and its applications to geologica problems, Annu. Rev. Earth Planet. Sci., 26, 519 572, doi:10.1146/annurev.earth.26.1.519.

Garzione, C. N., P. Molnar, J. Libarkin, and B. MacFadden (2006), Rapid late Miocene rise of the Bolivian Altiplano: Evidence for removal of mantle lithosphere, Earth Planet. Sci. Lett., 241, $543-$ 556, doi:10.1016/j.eps1.2005.11.026.

Gephart, J. (1994), Topography and subduction geometry in the central Andes: Clues to the mechanics of noncollisional orogen, J. Geophys. Res., 99, 12,279-12,288, doi:10.1029/94JB00129.

Ghosh, P., C. N. Garzione, and J. M. Eiler (2006), Rapid uplift of the Altiplano revealed through ${ }^{13} \mathrm{C}-{ }^{18} \mathrm{O}$ bonds in paleosol carbonates, Science, 311, 511-515, doi:10.1126/science.1119365.

Gillis, R. J., B. K. Horton, and M. Grove (2006), Thermochronology, geochronology, and upper crustal structure of the Cordillera Real: Implications for Cenozoic exhumation of the central Andean plateau, Tectonics, 25, TC6007, doi:10.1029/ 2005TC001887

Green, P. F. (1981), A new look at statistics in fissiontrack dating, Nucl. Tracks Radiat. Meas., 5, 77-86, doi:10.1016/0191-278X(81)90029-9.

Gubbels, T. L., B. L. Isacks, and E. Farrar (1993), Highlevel surfaces, plateau uplift, and foreland development, Bolivian central Andes, Geology, 21, 695 698, doi:10.1130/0091-7613(1993)021 $<0695$ :HLSPUA $>2.3 . \mathrm{CO} ; 2$

Hamza, V. M., and M. Muñoz (1996), Heat flow map of South America, Geothermics, 25, 599-646, doi:10.1016/S0375-6505(96)00025-9.

Hamza, V. M., J. S. S. F.Dias, A. J. L. Gomes, and Z. G D. Terceros (2005), Numerical and functional representations of regional heat flow in South America, Phys Earth Planet Inter, 152, 223-256.

Hasebe, N., A. Carter, A. J. Hurford, J. Barbarand, and K. Jarvis (2004), Apatite fission-track chronometry using laser ablation ICP-MS, Chem. Geol., 207, 135-145, doi:10.1016/j.chemgeo.2004.01.007.

Henry, S. G., and H. N. Pollack (1988), Terrestrial heat flow above the Andean subduction zone in Bolivia and Peru, J. Geophys. Res., 93, 15,153-15,162.

Hodges, K. V. (2003), Geochronology and thermochronology in orogenic systems, in Treatise on Geochemistry, edited by R. L. Rudnick, pp. 263-292, Elsevier, New York.
Horton, B. K. (1998), Sediment accumulation on top of the Andean orogenic wedge; Oligocene to late Miocene basins of the Eastern Cordillera, southern Bolivia, Geol. Soc. Am. Bull., 110, 1174-1192, doi:10.1130/0016-7606(1998)110<1174:SAOTOT $>2.3 . C O ; 2$.

Horton, B. K. (1999), Erosional control on the geometry and kinematics of thrust belt development in the central Andes, Tectonics, 18, 1292-1304, doi:10.1029/1999TC900051.

Horton, B. K. (2005), Revised deformation history of the central Andes: Inferences from Cenozoic foredeep and intermontane basins of the Eastern Cordillera, Bolivia, Tectonics, 24, TC3011, doi:10.1029/2003TC001619.

Horton, B. K., and P. G. DeCelles (1997), The modern foreland basin system adjacent to the Central Andes, Geology, 25, 895-898, doi:10.1130/00917613(1997)025<0895:TMFBSA $>2.3 . \mathrm{CO} ; 2$

Horton, B. K., B. A. Hampton, and G. L. Waanders (2001), Paleogene synorogenic sedimentation in the Altiplano plateau and implications for initial mountain building in the Central Andes, Geol. Soc. Am Bull., 113, 1387-1400, doi:10.1130/0016-7606 (2001) $113<1387$ :PSSITA $>2.0$. CO;2.

Horton, B. K., B. A. Hampton, B. N. Lareau, and E. Baldellon (2002), Tertiary provenance history of the northern and central Altiplano (central Andes, Bolivia); a detrital record of plateau-margin tectonics, J. Sediment Res., 72, 711-726, doi:10.1306/ 020702720711 .

Hulka, C., K.-U. Grafe, B. Sames, C. E. Uba, and C. Heubeck (2006), Depositional setting of the middle to late Miocene Yecua Formation of the Chaco Foreland Basin, southern Bolivia, J. S. Am. Earth Sci., 21, 135-150, doi:10.1016/j.jsames.2005. 08.003

Iaffaldano, G., H.-P. Bunge, and T. H. Dixon (2006), Feedback between mountain belt growth and plate convergence, Geology, 34, 893-896, doi:10.1130 G22661.1.

Instituto Geografico Militar (2000), Digital Atlas of Bolivia [CD-ROM], Inst. Geogr. Militar and Multisoft, La Paz, Bolivia.

Isacks, B. L. (1988), Uplift of the central Andean Plateau and bending of the Bolivian Orocline, J. Geophys. Res., 93, 3211-3231, doi:10.1029 JB093iB04p03211.

Jordan, T. E., J. H. Reynolds III, and J. P. Erikson (1997), Variability in age of initial shortening and uplift in the central Andes, in Tectonic Uplift and Climate Change, edited by W. F. Ruddiman, pp. 41-61, Plenum, New York.

Kay, R. F., B. J. MacFadden, R. H. Madden, H. Sandeman, and F. Anaya (1998), Revised age of the Salla beds, Bolivia, and its bearing on the age of the Deseadan South American land mammal "age", J. Vertebrate Paleontol., 18 , $189-199$

Kennan, L., S. Lamb, and J. Rundle (1995), K-Ar dates from the Altiplano and Cordillera Oriental of Bolivia: Implications for Cenozoic stratigraphy and tectonics, J. S. Am. Earth Sci., 8, $163-186$, doi:10.1016/0895-9811(95)00003-X.

Kennan, L., S. H. Lamb, and L. Hoke (1997), High-altitude palaeosurfaces in the Bolivian Andes; evidence for late Cenozoic surface uplift, in Palaeosurfaces, Recognition, Reconstruction and Palaeoenvironmental Interpretation, edited by M. Widdowson, Geol. Soc. Spec. Publ., 120, 307-323.

Ketcham, R. A. (2003), Observations on the relationship between crystallographic orientation and biasing in apatite fission-track measurements, $\mathrm{Am}$. Mineral., 88, 817-829.

Ketcham, R. A. (2005), Forward and inverse modeling of low-temperature thermochronometry data, in Low-Temperature Thermochronology: Techniques, Interpretations, and Applications, Rev. Mineral. Geochem., vol. 58, edited by P. W. Reiners and T. A. Ehlers, pp. 275-314, Mineral. Soc. of Am., Chantilly, Va. 
Ketcham, R. A., R. A. Donelick, and W. D. Carlson (1999), Variability of apatite fission-track annealing kinetics; III. Extrapolation to geological time scales, Am. Mineral., 84, 1235-1255.

Ketcham, R. A., R. A. Donelick, and M. B. Donelick (2000), AFTSolve: A program for multi-kinetic modeling of apatite fission-track data, Geol. Mater. Res., 2, 1-32.

Kley, J. (1996), Transition from basement-involved to thin-skinned thrusting in the Cordillera Oriental of southern Bolivia, Tectonics, 15, 763-775, doi:10.1029/95TC03868.

Kley, J. (1999), Geologic and geometric constraints on a kinematic model of the Bolivian Orocline, J.S Am. Earth Sci., 12, 221-235, doi:10.1016/S08959811(99)00015-2

Kley, J., and C. R. Monaldi (1998), Tectonic shortening and crustal thickness in the central Andes: How good is the correlation?, Geology, 26, 723-726, doi:10.1130/0091-7613(1998)026<0723:TSAC$\mathrm{TI}>2.3 . \mathrm{CO} ; 2$.

Kley, J., and M. Reinhardt (1994), Geothermal and tectonic evolution of the Eastern Cordillera and the Subandean ranges of southern Bolivia, in Tectonics of the Southern Central Andes: Structure and Evolution of an Active Continental Margin, edited by K. J. Reutter, E. Scheuber, and P. J. Wigger, pp. 155-170, Springer, Berlin, Germany.

Kley, J., J. Mueller, S. Tawackoli, V. Jacobshagen, and E. Manutsoglu (1997), Pre-Andean and Andeanage deformation in the Eastern Cordillera of southern Bolivia, J.S. Am. Earth Sci., 10, 1-19, doi:10.1016/S0895-9811(97)00001-1.

Kley, J., C. R. Monaldi, and J. A. Salfity (1999), Alongstrike segmentation of the Andean foreland: Causes and consequences, Tectonophysics, 301, 75-94, doi:10.1016/S0040-1951(98)90223-2.

Lamb, S., and P. Davis (2003), Cenozoic climate change as a possible cause for the rise of the Andes, Nature, 425, 792-797, doi:10.1038/nature02049.

Lamb, S., and L. Hoke (1997), Origin of the high plateau in the central Andes, Bolivia, South America, Tectonics, 16, 623-649, doi:10.1029/97TC00495.

Masek, J. G., B. L. Isacks, T. L. Gubbels, and E. J. Fielding (1994), Erosion and tectonics at the margins of continental plateaus, J. Geophys. Res., 99, 13,941-13,956.

McFadden, B. J., K. E. Campbell, R. L. Ciffelli, O. Siles, N. M. Johnson, C. W. Naeser, and P. K. Zeitler (1985), Magnetic polarity stratigraphy and mammalian fauna of the Deseadan (late Oligocene-early Miocene) Salla beds of northern Bolivia, J. Geol., 93, 233-250.

McQuarrie, N. (2002), The kinematic history of the central Andean fold-thrust belt, Bolivia; implications for building a high plateau, Geol. Soc. Am. Bull., 114, 950-963, doi:10.1130/0016-7606(2002) $114<0950$ :TKHOTC $>2.0 . \mathrm{CO} ; 2$.

McQuarrie, N., and G. H. Davis (2002), Crossing the several scales of strain-accomplishing mechanisms in the hinterland of the central Andean fold-thrust belt, Bolivia, J. Struct. Geol., 24, 1587-1602, doi:10.1016/S0191-8141(01)00158-4.

McQuarrie, N., and P. DeCelles (2001), Geometry and structural evolution of the central Andean backthrust belt, Bolivia, Tectonics, 20, 669-692, doi:10.1029/2000TC001232.

McQuarrie, N., B. K. Horton, G. Zandt, S. Beck, and P. G. DeCelles (2005), Lithospheric evolution of the Andean fold-thrust belt, Bolivia, and the origin of the central Andean plateau, Tectonophysics, 399, 15-37, doi:10.1016/j.tecto.2004.12.013.

McQuarrie, N., J. B. Barnes, and T. A. Ehlers (2008), Geometric, kinematic, and erosional history of the central Andean Plateau, Bolivia $\left(15-17^{\circ} \mathrm{S}\right), \mathrm{Tec}$ tonics, doi:10.1029/2006TC002054, in press.

Molnar, P., P. England, and J. Martinod (1993), Mantle dynamics, uplift of the Tibetan Plateau, and the Indian monsoon, Rev. Geophys., 31, 357-396, doi:10.1029/93RG02030.

Montgomery, D. R., G. Balco, and S. D. Willett (2001), Climate, tectonics, and the morphology of the An- des, Geology, 29, 579-582, doi:10.1130/00917613(2001)029<0579:CTATMO $>2.0 . \mathrm{CO} ; 2$.

Moretti, I., P. Baby, E. Mendez, and D. Zubieta (1996), Hydrocarbon generation in relation to thrusting in the Sub Andean Zone from 18 to $22^{\circ} \mathrm{S}$, Bolivia, Petrol. Geosci., 2, 17-28.

Müller, J. P., J. Kley, and V. Jacobshagen (2002), Structure and Cenozoic kinematics of the Eastern Cordillera, southern Bolivia (21(S), Tectonics, 21(5), 1037, doi:10.1029/2001TC001340.

Oncken, O., D. Hindle, J. Kley, K. Elger, P. Victor, and K. Schemmann (2006), Deformation of the centra Andean upper plate system-Facts, fiction, and constraints for plateau models, in The Andes: Active Subduction Orogeny, edited by O. Oncken et al., pp. 3-27, Springer, Berlin, Germany.

Pardo-Casas, F., and P. Molnar (1987), Relative motion of the Nazca (Farallon) and South American plates since Late Cretaceous time, Tectonics, 6, 233-248, doi:10.1029/TC006i003p00233.

Press, W. H., B. P. Flannery, S. A. Teukolsky, and W. T. Vetterling (1992), Numerical Recipes in C, 1020 pp., Cambridge Univ. Press, New York.

Ramos, V. A., T. Zapata, E. O. Cristallini, and A. Introcaso (2004), The Andean thrust system; latitudinal variations in structural styles and orogenic shortening, in Thrust Tectonics and Hydrocarbon Systems, edited by K. R. McClay, AAPG Mem., 82, 30-50.

Reiners, P. W., and M. T. Brandon (2006), Using thermochronology to understand orogenic erosion, Annu. Rev. Earth Planet. Sci., 34, 419-466, doi:10.1146/annurev.earth.34.031405.125202.

Riera-Kilibarda, C., R. Roessling, and H. G. Mylius (1994), Geologia del Campo Volcanico Los Frailes-Kari Kari y la Franja Metalifera entre Potosi y Tupiza, edited by D. d. P, 2004 pp., Serv. Geol. de Bolivia, La Paz, Bolivia.

Ring, U., M. T. Brandon, S. D. Willett, and G. S. Lister (1999), Exhumation processes, in Exhumation Processes: Normal Faulting, Ductile Flow and Erosion, edited by U. Ring et al., Geol. Soc. Spec. Publ., 154, 1-27.

Roeder, D. (1988), Andean-age structure of eastern Cordillera (province of La Paz, Bolivia), Tectonics, 7, 23 -39, doi:10.1029/TC007i001p00023.

Roeder, D., and R. L. Chamberlain (1995), Structural geology of sub-Andean fold and thrust belt in northwestern Bolivia, in Petroleum Basins of South America, edited by A. J. Tankard, R. Suarez, and H. J. Welsink, AAPG Mem., 62, 459-479.

Royden, L. (1996), Coupling and decoupling of crust and mantle in convergent orogens: Implications for strain partitioning in the crust, J. Geophys. Res. 101, 17,679-17,705.

Ruddiman, W. F., M. E. Raymo, W. L. Prell, and J. E. Kutzbach (1997), The uplift-climate connection: A synthesis, in Tectonic Uplift and Climate Change, edited by W. F. Ruddiman, pp. 471-515, Plenum, New York

Safran, E. B., A. Blythe, and D. Thomas (2006), Spatially variable exhumation rates in orogenic belts: An Andean example, J. Geol., 114, 665-681, doi:10.1086/507613

Scheuber, E., D. Mertmann, H. Ege, P. Silva-Gonzalez, C. Heubeck, K.-J. Reutter, and V. Jacobshagen (2006), Exhumation and basin development related to formation of the central Andean plateau, $21^{\circ} \mathrm{S}$, in The Andes: Active Subduction Orogeny, edited by O. Oncken et al., pp. 285-301, Springer, Berlin, Germany

Schildgen, T. F., K. V. Hodges, K. X. Whipple, P. W. Reiners, and M. S. Pringle (2007), Uplift of the western margin of the Andean Plateau revealed from canyon incision history, southern Peru, Geology, 35, 523-526, doi:10.1130/G23532A.1.

Sempere, T. (1995), Phanerozoic evolution of Bolivia and adjacent regions, in Petroleum Basins of South America, edited by A. J. Tankard, R. Suarez, and H. J. Welsink, AAPG Mem., 62, 207-230.

Sempere, T., G. Herail, J. Oller, and M. G. Bonhomme (1990), Late Oligocene-early Miocene major tec- tonic crisis and related basins in Bolivia, Geology, 18, 946-949, doi:10.1130/0091-7613 (1990)018< 0946:LOEMMT>2.3.CO;2.

Sempere, T., R. Butler, D. Richards, L. Marshall, W. Sharp, and C. Swisher (1997), Stratigraphy and chronology of Upper Cretaceous-lower Paleogene strata in Bolivia and northwest Argentina, Geol. Soc. Am. Bull., 109, 709-727, doi:10.1130/00167606(1997) $109<0709$ :SACOUC $>2.3 . C O ; 2$.

Sempere, T., et al. (2002), Late Permian-Middle Jurassic lithospheric thinning in Peru and Bolivia, and its bearing on Andean-age tectonics, Tectonophysics, 345(1), 153-181, doi:10.1016/S0040-1951(01)00211-6.

Sobel, E. R., and M. R. Strecker (2003), Uplift, exhumation and precipitation: tectonic and climatic control of late Cenozoic landscape evolution in the northern Sierras Pampeanas, Argentina, Basin Res., 15, 431-451, doi:10.1046/j.1365-2117. 2003.00214.x

Sobel, E. R., G. E. Hilley, and M. R. Strecker (2003), Formation of internally drained contractional basins by aridity-limited bedrock incision, J. Geophys. Res., 108(B7), 2344, doi:10.1029/2002JB001883.

Springer, M. (1999), Interpretation of heat-flow density in the Central Andes, in Thermal Regimes in the Continental and Oceanic Lithosphere, edited by C. Clauser, T. Lewis, and L. Rybach, pp. $377-$ 395, Elsevier, Amsterdam, Netherlands.

Springer, M., and A. Forster (1998), Heat-flow density across the central Andean subduction zone, Tectonophysics, 291 , 123-139, doi:10.1016/S0040-1951(98)00035-3.

Tagami, T., and P. B. O'Sullivan (2005), Fundamentals of fission-track thermochronology, in Low-Temperature Thermochronology: Techniques, Interpretations, and Applications, Rev. Mineral. Geochem., vol. 58, edited by P. W. Reiners and T. A. Ehlers, pp. 19-47, Mineral. Soc. of Am., Chantilly, Va.

Trumbull, R. B., R. Ulrich, O. Oncken, S. Ekkehard, K. Munier, and F. Hongn (2006), The time-space distribution of Cenozoic volcanism in the south-central Andes: a new data compilation and some tectonic implications, in The Andes: Active Subduction Orogeny, edited by O. Oncken et al., pp. 29-43, Springer, Berlin, Germany.

Uba, C. E., C. Heubeck, and C. Hulka (2006), Evolution of the late Cenozoic Chaco foreland basin, southern Bolivia, Basin Res., 18, 145-170, doi:10.1111/j.1365-2117.2006.00291.x.

Wdowinski, S., and Y. Bock (1994), The evolution of deformation and topography of high elevated plateaus: 2. Application to the central Andes, J. Geophys. Res., 99(B4), 7121-7130, doi:10.1029/ 93JB02396.

Welsink, H. J., M. A. Franco, and G. C. Oviedo (1995), Andean and pre-Andean deformation, Boomerang Hills area, Bolivia, in Petroleum Basins of South America, edited by A. J. Tankard, R. Suarez, and H. J. Welsink, AAPG Mem., 62, 481-499.

Willett, S. (1992), Dynamic and kinematic growth and change of a Coulomb wedge, in Thrust Tectonics, edited by K. McClay, pp. 19-31, Chapman and Hall, London.

Willett, S. D. and D. C. Pope (2004), Thermo-mechanical models of convergent orogenesis Thermal and rheologic dependence of crustal deformation, in Rheology and Deformation of the Lithosphere at Continental Margins, edited by G. D. Karner et al., pp. 179222, Columbia Univ. Press, New York

J. B. Barnes and T. A. Ehlers, Department of Geological Sciences, University of Michigan, $1100 \mathrm{~N}$. University Avenue, Ann Arbor, MI 48109-1005, USA (barnesja@umich.edu)

N. McQuarrie, Department of Geosciences, Princeton University, 207 Guyot Hall, Princeton, NJ 08544, USA

P. B. O'Sullivan, Apatite to Zircon, Inc., 1075 Matson Road, Viola, ID, 83872-9709, USA

S. Tawackoli, Técnico Internacional Programa APEMIN-II, Av. del Minero s/n, Casilla 54, Oruro, Bolivia. 